\title{
Age-Related Impairment in the 250-Millisecond Delay Eyeblink Classical Conditioning Procedure in C57BL/6 Mice
}

\author{
Richard W. Vogel, ${ }^{1}$ Michael Ewers, ${ }^{2}$ Charlene Ross, ${ }^{1}$ Thomas J. Gould, ${ }^{1,2}$ \\ and Diana S. Woodruff-Pak ${ }^{1,2,3}$ \\ ${ }^{1}$ Research and Technology Development, Albert Einstein Healthcare Network, Philadelphia, Pennsylvania 19141, USA; ${ }^{2}$ Department \\ of Psychology, Temple University, Philadelphia, Pennsylvania 19122, USA
}

\begin{abstract}
In this study we tested 4-, 9-, 12-, and 18-month-old C57BL/6 mice in the 250-msec delay eyeblink classical conditioning procedure to study age-related changes in a form of associative learning. The short life expectancy of mice, complete knowledge about the mouse genome, and the availability of transgenic and knock-out mouse models of age-related impairments make the mouse an excellent species for expanding knowledge on the neurobiologically and behaviorally well-characterized eyeblink classical conditioning paradigm. Based on previous research with delay eyeblink conditioning in rabbits and humans, we predicted that mice would be impaired on this cerebellar-dependent associative learning task in middle-age, at $\sim 9$ months. To fully examine age differences in behavior in mice, we used a battery of additional behavioral measures with which to compare young and older mice. These behaviors included the acoustic startle response, prepulse inhibition, rotorod, and the Morris water maze. Mice began to show impairment in cerebellar-dependent tasks such as rotorod and eyeblink conditioning at 9 to 12 months of age. Performance in hippocampally dependent tasks was not impaired in any group, including 18-month-old mice. These results in mice support results in other species, indicating that cerebellar-dependent tasks show age-related deficits earlier in adulthood than do hippocampally dependent tasks.
\end{abstract}

The eyeblink classical conditioning paradigm is a powerful tool for studying learning and memory because it is wellcharacterized on a neurobiological and behavioral basis. In addition, the sensitivity, reliability, and generalization across species that eyeblink conditioning has shown is remarkable. There are more published studies on rabbits and humans tested in eyeblink classical conditioning than on any other form of Pavlovian conditioning. Furthermore, dramatic parallels exist between the effects of normal aging in rabbits and humans in eyeblink conditioning. Given the short life expectancy of mice, the fact that the mouse genome is mapped, and the availability of transgenic and knock-out mouse models of neurodegenerative diseases related to aging, the mouse is an excellent species for expanding knowledge on age effects in eyeblink classical conditioning.

The delay eyeblink classical conditioning procedure is frequently used in conditioning studies. In the delay procedure, a neutral stimulus such as a tone conditioned stimulus (CS) is presented shortly before a blink-eliciting unconditioned stimulus (US), such as a puff of air directed to the

${ }^{3}$ Corresponding author.

E-MAIL woodrufd@einstein.edu; FAX (215) 456-8122.

Article and publication are at http://www.learnmem.org/cgi/doi/ $10.1101 / \mathrm{lm} .50902$. eye. The two stimuli then briefly overlap and coterminate. After many pairings, the organism associates the stimuli and learns to blink to the tone CS in anticipation of the airpuff US. This behavior is characterized as a conditioned response (CR).

The neural circuitry underlying formation of CRs has been almost entirely delineated, and striking parallels have been observed between several mammalian species (Daum and Schugens 1996; Thompson 2000; Woodruff-Pak and Steinmetz 2000a,b). The essential site responsible for acquisition and retention resides in the cerebellum, ipsilateral to the conditioned eye (Thompson 1986). The cerebellum receives converging CS and US information, and develops learning-related neural activity during conditioning. Lesions of cerebellar cortex disrupt learning (Lavond and Steinmetz 1989). Although not essential for delay eyeblink conditioning, the hippocampus can modulate the rate of learning in delay conditioning, increasing or slowing the rate of learning (Berger et al. 1986). Age differences in the cerebellum (Woodruff-Pak et al. 1990a) and hippocampus (Disterhoft and McEchron 2000) with normal aging are associated with deficits in eyeblink conditioning. Age-related impairments in eyeblink conditioning are documented in humans (Solomon et al. 1989; Woodruff-Pak and Thompson 1988), rabbits (Woodruff-Pak et al. 1987), cats (Harrison and

LEARNING \& MEMORY 9:321-336 @ 2002 by Cold Spring Harbor Laboratory Press ISSN1072-0502/02 \$5.00

$$
\begin{aligned}
& \begin{array}{lllllllllllllllll}
L & E & A & R & N & I & N & G & \boldsymbol{Z} & M & E & M & O & R & Y
\end{array} \\
& \text { www.learnmem.org }
\end{aligned}
$$


Buchwald, 1983), rats (Weiss and Thompson 1991), and mice (Kishimoto et al. 2001).

Additional serious impairment in eyeblink conditioning, beyond that observed in normal aging, has been observed in older adults with Alzheimer's disease (AD) (Woodruff-Pak et al. 1990b, 1996; Solomon et al. 1991). Furthermore, the 400-msec delay procedure may detect $\mathrm{AD}$ at a preclinical phase (Ferrante and Woodruff-Pak 1995; Downey-Lamb and Woodruff-Pak 1999). Thus, the eyeblink conditioning paradigm is a fundamental tool for studying age- and neurodegeneration-related changes in the brain.

Nonhuman mammalian models of eyeblink conditioning, with life expectancies shorter than the 76.9-year human life expectancy, provide a means to focus and experiment with processes of aging. The rabbit model has been used extensively. However, rabbit life expectancy is 8 years, far exceeding that of rodents. With the rapid evolution of mouse genetics, mouse models have gained increased attention in the neurobiology of aging (Jucker and Ingram 1997). The short lifespan of mice and the extensive knowledge base on mouse genetics are among the qualities that make this species an excellent animal model for investigation of learning, memory, and aging. Techniques for testing rats, including neonatal rats, have been recently created (Stanton and Freeman 2000), along with techniques to test eyeblink classical conditioning in normal, mutant, and transgenic mouse strains (Kim and Thompson 1997). Thus, the mouse model has recently emerged as a promising direction for future study.

If aging mice are to be tested in the eyeblink conditioning paradigm, it is imperative that age parallels also be drawn between mice and other species. Using reproductive capacity as a biomarker, mice aged 2 months can reproduce and are roughly comparable to 4- to 6-month-old rabbits and adolescent humans. Likewise, an 8-month-old mouse begins to show decline in reproductive capacity and is comparable to an 18-month-old rabbit or a middle-aged human. On the basis of results in rabbits and humans, it is likely then that age-related impairments in eyeblink conditioning will begin in mice shortly after 8 mo.

In the first published study of eyeblink conditioning in aging C57BL/6 mice, Kishimoto et al. (2001) reported agerelated impairment in the 252 -msec delay procedure in 20month-old mice. The result of impairment only in very old mice is not completely parallel with studies in rabbits and humans. Age differences are observed in rabbits in the 750msec delay eyeblink conditioning procedure by $24 \mathrm{mo}-$ the age when reproductive capacity begins to decline (for summary, see Green and Woodruff-Pak 2000). The longer 750msec CS-US interval is significantly more difficult for both young and older rabbits. Age differences in the delay procedure at the shorter and less difficult CS-US interval, 250 msec, occur at a later age in rabbits -36 months (Coffin and
Woodruff-Pak 1993). Based on life expectancy, a 20-monthold mouse is comparable to an 80-month-old rabbit. However, we observed age-related deficits in the 250-msec delay procedure in 36-month-old rabbits. Extrapolating rabbit life expectancy to mouse life expectancy, data from our laboratory indicate that mice should show age-related impairment in the $250-\mathrm{msec}$ delay eyeblink conditioning procedure around the age of 9 mo.

To examine fully age-related impairments in mice, we have developed a test battery to compare young and older mice across multiple behaviors. These behaviors include the acoustic startle response, prepulse inhibition, rotorod, and the Morris water maze. Acoustic startle response is a test that has been used previously to examine hearing abilities in mice (Parham and Willott 1988). Several studies have pointed out that middle-aged C57BL/6 mice begin to show presbycusis, and that this age-related hearing loss can be profound (Mikaelian 1979; Henry and Chole 1980; Henry 1983; Hunter and Willott 1987; Parham and Willott 1988; Erway et al. 1993; Zheng et al. 1999). The acoustic startle response and prepulse inhibition are measures that we use to ensure that auditory acuity is not a confound in our eyeblink classical conditioning measures of learning and memory that use an auditory CS. Prepulse inhibition is also a measure that provides insight into mechanisms of sensorimotor gating, alertness, information processing, and attention (Dawson et al. 1999). These processes are affected in normal aging and $\mathrm{AD}$, and prepulse inhibition in aging C57BL/6 mice shows decline around 18 months of age (Ison et al. 1998). Rotorod is a motor learning and coordination task for which the cerebellum is essential. Purkinje cell loss with age reduces cerebellar volume. Because deficits in the cerebellar-dependent eyeblink conditioning paradigm begin to appear in middle age, and because these deficits are associated with a reduction in cerebellar volume, it is useful to compare performance decline in these cerebellar-dependent tasks. The Morris water maze is a hippocampally dependent spatial learning task. The hippocampus is affected profoundly in $\mathrm{AD}$, and it is necessary to examine the integrity of the hippocampus in normal aging.

We predicted that age differences in the cerebellardependent eyeblink conditioning and rotorod tasks would occur at an earlier age than do age differences in the hippocampally dependent Morris water maze task. The prediction for age differences in acoustic startle and prepulse inhibition performance was that they should occur at an intermediate age between the age at which eyeblink conditioning and rotorod deficits appear and the age at which Morris water maze deficits appear. Taken together, these results with eyeblink conditioning and other behavioral tasks will help to integrate eyeblink classical conditioning data into the extensive body of research literature on aging mice.

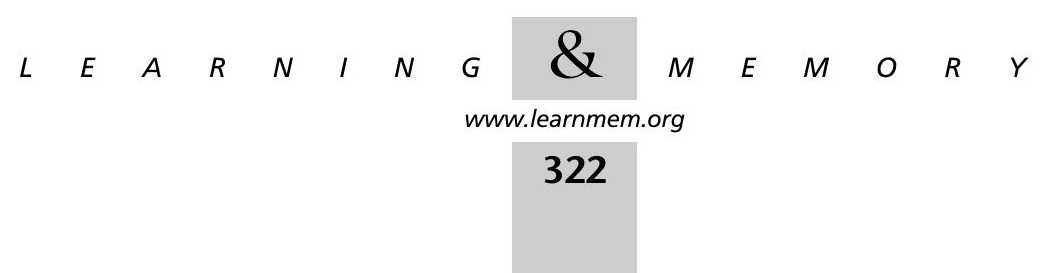




\section{RESULTS}

\section{Age Differences in Eyeblink Classical Conditioning}

Paired CS and US data were first collected for 10 days from 9- and 12-month-old groups. These preliminary data were hand-scored by a trained technician who observed the mouse in the conditioning chamber and scored CRs when an eyeblink response to the tone CS occurred before a head twitch response to the shock US. Because the responses were scored by direct visual observation in the short 250msec CS-US interval, response latencies were not assessed. It was not possible to correct the responses scored as CRs with short-latency responses, and it was also difficult to eliminate all of the bad trials that included eyeblinks before CS onset in the hand-scored analysis. A 2 (age group) $\times 10$ (training session) repeated- measures analysis of variance (ANOVA) determined that age differences in percentage of CRs were not significant $\left(\mathrm{F}_{[1,12]}=3.56, P=0.083\right)$. There was a significant effect of acquisition of CRs over trials $\left(\mathrm{F}_{[9,108]}=8.04, P<0.0001\right.$; Fig. 1).

Paired CS and US data were then collected for $10 \mathrm{~d}$ from 4 - and 18-month-old groups, and for $5 \mathrm{~d}$ from a different group of 12-month-old mice. Data in the explicitly unpaired condition in which the CS and US are presented independently were also collected from a 4-month-old group for $5 \mathrm{~d}$. These data were scored by a computer as described in the Materials and Methods section. To determine if our hand-scoring method was comparable to the computer-scoring methods, we compared five sessions of acquisition data in 12-month-old mice tested with the handor computer-scoring methods. A 2 (scoring method) $\times 5$

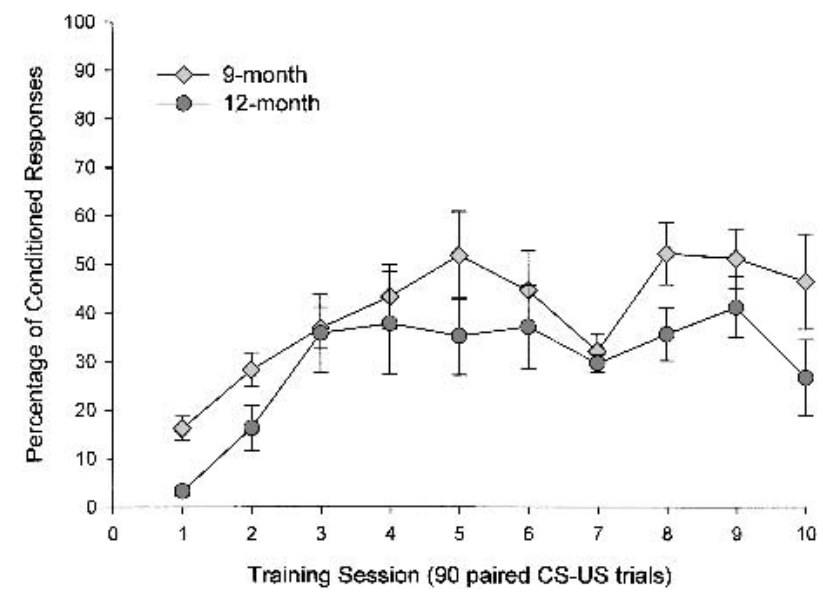

Figure 1 Percentage of conditioned responses (CRs) in mice aged $9(n=7)$ and $12(n=7)$ months over ten 90-paired trial sessions in the 250-msec delay eyeblink classical conditioning procedure as assessed by hand-scoring of CRs. Hand-scored data indicate that mice aged 9 and 12 months acquire CRs at a similar rate. CRs are hand-scored by observing blinking to a $10-\mathrm{kHz}$ tone conditioned stimulus (CS) just before a head twitch response to the $0.5-\mathrm{mA}$ shock unconditioned stimulus (US). (training session) repeated-measures ANOVA revealed no significant scoring method, training session, or interaction effect, indicating that our hand-scoring and computer-scoring methods were roughly comparable for assessing percentage of CRs.

Rapid acquisition occurred in 4-, 12-, and 18-month-old mice over five training sessions, although the young mice acquired CRs more rapidly than did the older mice. Using the dependent measure of percentage of CRs, a 3 (age group) $\times 5$ (training session) repeated-measures ANOVA was conducted. This analysis revealed a significant main effect for training session $\left(\mathrm{F}_{[4,84]}=11.37, P<0.001\right)$, and a significant interaction between age group and training session $\left(\mathrm{F}_{[8,84]}=2.94, P<0.01\right.$; Fig. 2$)$. The age group effect was not significant. Using the dependent measure of CR onset latency, a 3 (age group) $\times 5$ (training session) repeated-measures ANOVA was conducted. This analysis revealed a significant interaction between age group and training session $\left(\mathrm{F}_{[8,84]}=2.23, P<0.05\right)$, which occurred because CR onset latency declined over sessions in the 12month-old group but remained relatively stable in the 4-and 18-month-old groups. The main effect for training session approached significance $(P=0.07)$, and the age group effect was not significant.

Using the dependent measure of percentage of shortlatency responses (responses occurring between 0 and 80 msec after CS onset that have traditionally been called $\alpha$ or startle responses), a 3 (age group) $\times 5$ (training session) repeated-measures ANOVA was conducted. This analysis revealed a significant main effect for training session $\left(\mathrm{F}_{[4,84]}=6.13, P<0.0001\right)$, as well as a significant interaction between age group and training session $\left(\mathrm{F}_{[8,84]}=2.66\right.$, $P<0.05)$. There was not a significant age group effect. Whereas the 4-month-old group showed no difference in short-latency responses across training sessions, both 12and 18-month-old groups produced significantly more short-latency responses on training session 2 than on training session 1. The number of short-latency responses produced by these groups did not increase significantly beyond training session 2 .

A 3 (age group) $\times 5$ (training session) repeated-measures ANOVA was conducted on the number of excluded bad trials. There were no significant age group or training session effects, and no interaction between age group and training session was observed. Except in rare circumstances, the number of excluded trials generally remained $<10$ (10\%), with most training sessions excluding $<5 \%$ of the trials.

For the 4- and 18-month-old mice on which there were data for 10 training sessions, a 2 (age group) $\times 10$ (training session) repeated-measures ANOVA revealed a significant training session effect $\left(\mathrm{F}_{[9,126]}=2.98, P<0.01\right)$ and a significant interaction between age group and training session $\left(\mathrm{F}_{[9,126]}=2.31, P<0.05\right.$; Fig. 3$)$. The age group effect was

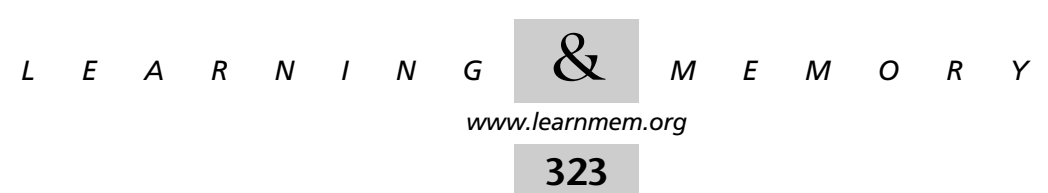




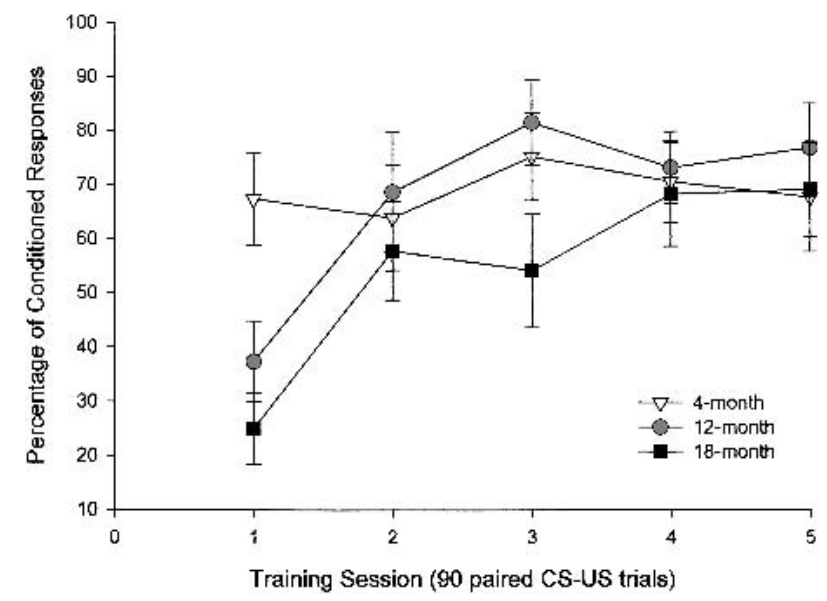

Figure 2 Percentage of conditioned responses (CRs) in mice aged $4(n=8), 12(n=8)$, and $18(n=8)$ months over five 90-paired trial sessions in the 250-msec delay eyeblink classical conditioning procedure as assessed by computer scoring of CRs. CRs are scored by the computer if electromyography activity in the orbicularis oculi muscle exceeds 5 standard deviations above baseline activity between 80 and 250 msec after the CS onset.

not significant. Using the dependent measure of CR onset latency, a 2 (age group) $\times 10$ (training session) repeatedmeasures ANOVA was conducted. This analysis revealed no significant main effects and no interaction between age group and training session. Nevertheless, mice in both age groups decreased their CR onset latencies numerically from the first to the last training session. CR onset latency for mice in training session 1 was 121.1 and $119.8 \mathrm{msec}$ for young and old mice, respectively. CR onset latency in training session 10 was 115.1 and $111.7 \mathrm{msec}$ for young and old

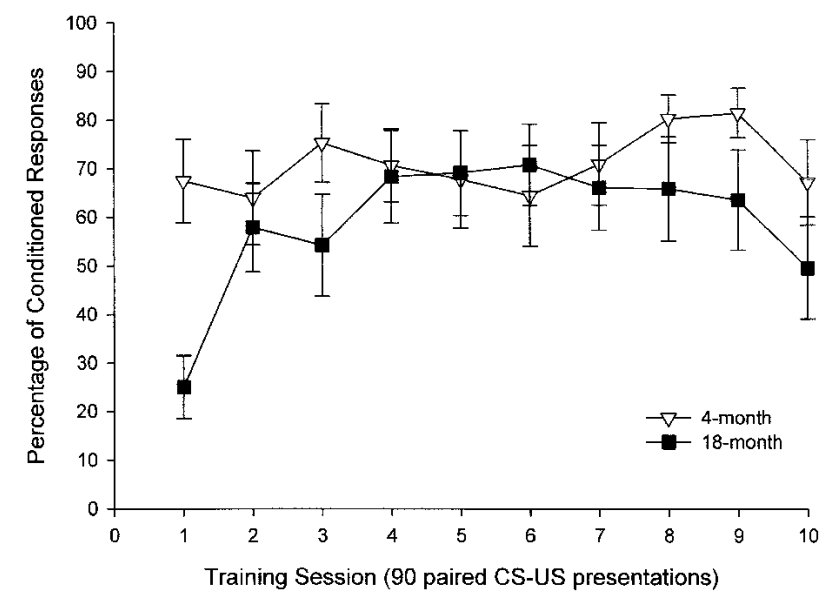

Figure 3 Percentage of conditioned responses (CRs) in mice aged $4(n=8)$ and $18(n=8)$ months over ten 90-paired trial sessions in the 250-msec delay eyeblink classical conditioning procedure as assessed by computer scoring of CRs. Data from young and old mice indicate that young mice show ceiling performance on the first day, whereas old mice do not perform at a comparable level until the second day of training. mice, respectively. Using the dependent measure of percentage of short-latency responses, a 2 (age group) $\times 10$ (training session) repeated-measures ANOVA was conducted. This analysis revealed a significant main effect for training session $\left(\mathrm{F}_{[9,126]}=2.67, P<0.01\right)$, as well as a significant interaction between age group and training session $\left(\mathrm{F}_{[9,126]}=2.28, P<0.05\right)$. The age group effect was not significant. Whereas the 4-month-old group showed no difference in short-latency responses across training sessions, 18-month-old mice produced significantly more short-latency responses on training sessions $4,7,8$, and 9 than on training session 1 . A 2 (age group) $\times 10$ (training session) repeated-measures ANOVA was conducted on the number of excluded bad trials. Neither the main effects nor the interaction was significant.

Because young mice produced such a high percentage of CRs in the first training session, the data were analyzed block by block (groups of nine paired trials/block) over the first training session in a 3 (age group) $\times 10$ (block of nine paired trials) repeated-measures ANOVA. There was a significant effect of age $\left(\mathrm{F}_{[2,21]}=21.51, P<0.0001\right)$. A post hoc analysis using the Tukey honestly significant difference test (HSD) indicated that 4-month-old mice significantly outperformed both 12- and 18-month-old mice on the first day of acquisition (Fig. 4A). There was also a significant effect of training block $\left(\mathrm{F}_{[9,189]}=2.27, P<0.02\right)$ and a significant age group by training session interaction $\left(\mathrm{F}_{[18,189]}=2.70\right.$, $P<0.0001)$. Given this significant interaction, we performed a one-way repeated-measures analysis for the 4-month-old group, comparing percentage of CRs over the 10 training blocks. There was a significant simple main effect of block within the group of 4-month-olds $\left(\mathrm{F}_{[9,63]}=4.19, P<0.0001\right)$, indicating that learning occurred in this group throughout the first 100 trials of training. Block-by block analysis for training session 2 indicated that there were no group differences on this subsequent training day (Fig. 4B). Percentage of CRs collected in 4-month-old mice in the paired and explicitly unpaired conditions over five training sessions were compared using a 2 (condition) $\times 5$ (training session) repeated-measures ANOVA. Group differences were revealed $\left(\mathrm{F}_{[1,14]}=21.37\right.$, $P<0.0001$ ), indicating percentage of CRs in the paired CSUS condition were significantly greater than were responses in a CR period in the unpaired condition (Fig. 5).

\section{Age Differences in Rotorod}

Two dependent measures, taken from the rotorod task that are often examined as indicators of motor coordination and motor learning are walk time and latency to fall. Walk time is a measure of the time that the mouse is actively walking on the rotating beam. Latency to fall is a measure of the amount time the mouse is able to avoid falling. Because mice may have a tendency to grip the rotorod and passively rotate rather than actively locomote, these two dependent

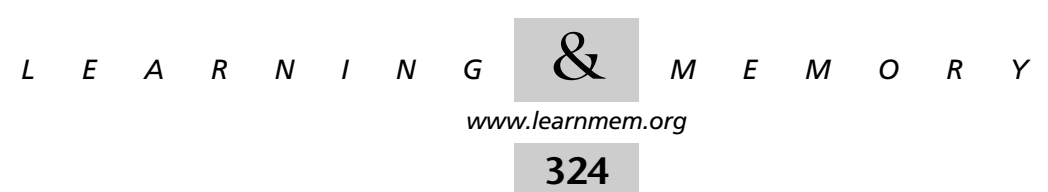


A

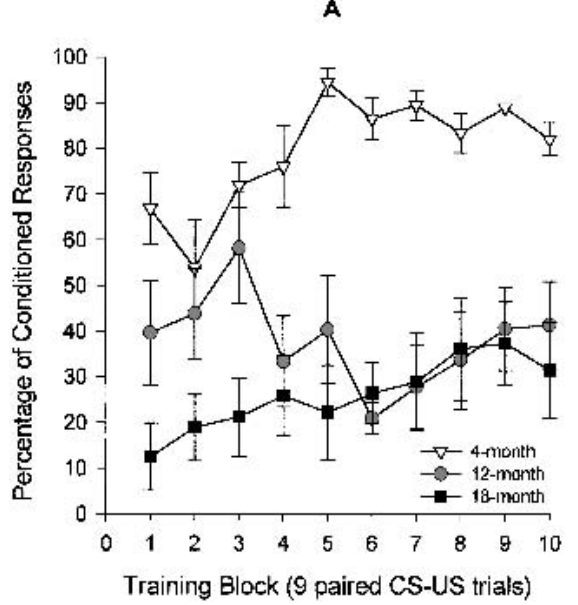

B

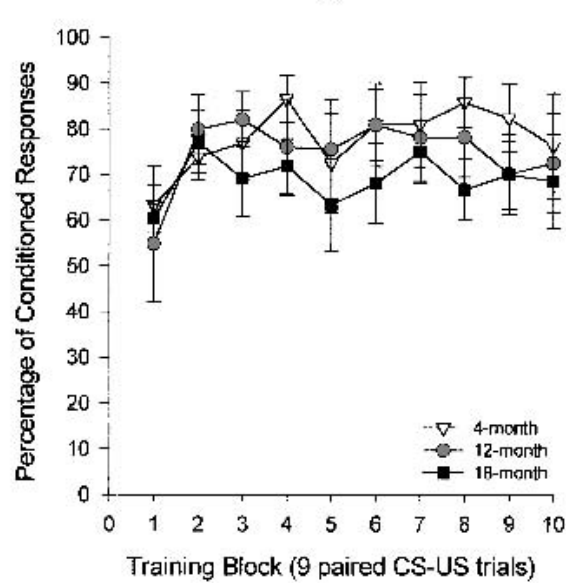

Figure 4 (A) Percentage of conditioned responses (CRs) on session 1 in mice aged $4(n=8), 12$ $(n=8)$, and $18(n=8)$ months over 10 nine-paired trial blocks in the 250-msec delay eyeblink classical conditioning procedure as assessed by computer scoring of CRs. Block-by-block CR acquisition on the first day of training reveals that older mice acquire CRs considerably more slowly than do young mice. (B) Percentage of CRs on session 2 in the same mice over 10 ninepaired trial blocks in the 250-msec delay eyeblink classical conditioning procedure as assessed by computer scoring of CRs. The second day of acquisition shows that age-related differences in percent CR do not extend beyond the first training session.

measures may differ. Paired samples $t$ tests were conducted between the daily mean for walk time and latency to fall at each rotation speed. The absence of significant differences indicated that mice spent their time on the rotorod actively walking rather than passively rotating.

Because no difference was revealed between walk time and latency to fall, the latter measure was used in the present analyses to assess motor abilities. Figure 6 depicts the rotorod performance of all age groups at both 15 and 25 revolutions per minute (rpm). A 3 (age group) $\times 3$ (training session) repeated-measures ANOVA, analyzing the 15-rpm data set, revealed a significant main effect for age group $\left(\mathrm{F}_{[2,80]}=8.17, \quad P<0.01\right)$ and for training session $\left(\mathrm{F}_{[2,160]}=182.18, P<0.001\right)$, as well as a significant interaction between age group and training $\left(\mathrm{F}_{[4,160]}=5.01\right.$, $P<0.01)$. Examining the main effect of training session within each age group, post hoc tests using the Bonferroni adjustment for multiple comparisons indicated that learning occurred in all groups. The 18-month-old group showed a significant difference in latency to fall between the training sessions, showing longer latencies each session. The 4 - and 12-month-old groups both showed significant motor learning between the first and second training sessions, and no difference between sessions 2 and 3 . This result most likely indicates ceiling performance in the 15 -rpm rotorod task by session 2 in young and middle-aged mice. A Tukey HSD post hoc test determined that the 4-month-old group outperformed the 12-month-old group in session 1, as well as the 18-month-old group in sessions 1 and 2 of the 15-rpm rotorod task. There were no differences between 12 - and 18- month-old 15-rpm rotorod performance in any training session (Fig. 6).

A 3 (group) $\times 3$ (training session) repeated-measures ANOVA, analyzing the 25-rpm data set, also revealed

a significant main effect for age group $\left(\mathrm{F}_{[2,80]}=21.30, P<0.001\right)$ and training session $\left(\mathrm{F}_{[2,160]}=92.81, \quad P<0.001\right), \quad$ as well as a significant interaction between age group and training ses$\operatorname{sion}\left(\mathrm{F}_{[4,160]}=2.57, P<0.05\right)$. Examining the main effect of training session within each age group, simple effects tests revealed the degree to which repeated training was effective in improving 25-rpm rotorod performance in each age group. Significant differences were revealed in the 4-month $\left(\mathrm{F}_{[2,79]}=16.78, \quad P<0.001\right), \quad 12$ month $\left(\mathrm{F}_{[2,79]}=40.23, P<0.001\right)$, and 18-month-old groups $\left(\mathrm{F}_{[2,79]}=23.92, P<0.001\right)$. Post hoc tests using the Bonferroni adjustment for multiple comparisons found that learning occurred in all groups. The 12and 18-month-old groups showed a significant difference in latency to fall between the training sessions, showing longer latencies each session. The 4-month-old group showed significant motor learning between the first and second test session, and no difference between sessions 2 and 3. This most likely indicates ceiling performance in the $25-\mathrm{rpm}$ rotorod task by session 2 in young mice. A Tukey HSD post hoc test determined that the 4-month-old group outperformed the 12-month-old group on sessions 1 and 2, as well as the 18-month-old group on all training sessions of the 25-rpm rotorod task. There were no differences between 12- and 18-month-old 25-rpm rotorod performance on any training session (Fig. 6).

A Pearson product-moment correlation was performed between percentage of CRs on the first training day for the 46 mice in the age range of 4 to 18 months that were tested with the 250-msec eyeblink classical conditioning procedure and rotorod. The latency to remain on the rotorod at $25 \mathrm{rpm}$ was positively correlated with percentage of CRs $(r=0.56, P=0.004)$. Percentage of CRs was not correlated at significant level with dependent measures from the acoustic startle, prepulse inhibition, or Morris water maze assessments.

\section{Age Differences in Acoustic Startle}

The intensity of a startle response is measured according to the amount of stabilimeter deflection that a mouse's body

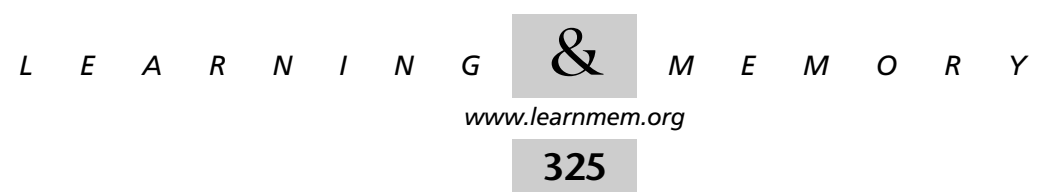




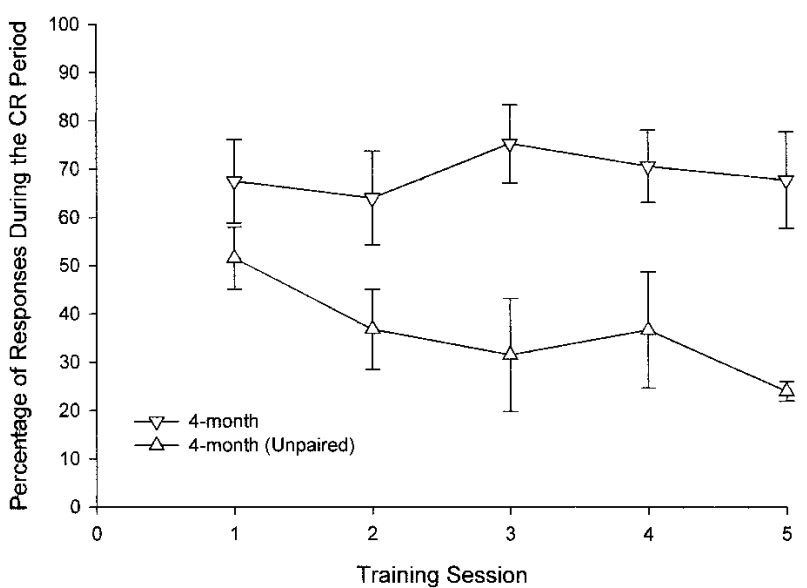

Figure 5 Percentage of responses, as assessed by computer scoring, to a $10-\mathrm{kHz}$ tone stimulus in mice aged 4 months $(n=8)$ who received paired conditioned stimulus (CS)-unconditioned stimulus (US) training in the 250-msec delay eyeblink classical conditioning procedure, and 4 months $(n=8)$ who received explicitly unpaired presentations of the CS and US. Eyeblink data from 4-month-old mice shows that mice in the paired CS-US procedure produce significantly more responses than do mice in the explicitly unpaired procedure. Responses during the CR period decreased from day 1 to day 5 in the explicitly unpaired procedure.

movement causes when it is presented with an auditory stimulus. The deflection is transduced into a congruent electrical pulse, which is read into the computer in millivolts. Response intensity is expressed as Vmax, the measure of maximum voltage transduced when movement occurs in the startle chamber. It is possible that the weight of an animal may contribute to the intensity of the response, and

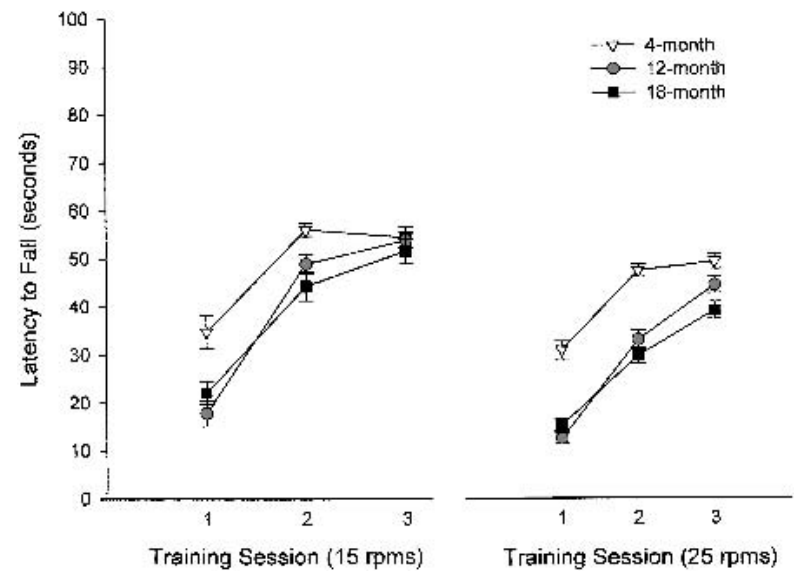

Figure 6 Rotorod performance of mice aged $4 \quad(n=28), 12$ $(n=27)$, and $18(n=28)$ months, at 15 or 25 revolutions per minute (rpm), over three test days. Learning in the cerebellar-dependent rotorod task is impaired in older mice at both 15 and 25 $\mathrm{rpm}$. The 15-rpm procedure is sensitive to deficits found in 18month-old mice. These mice do not perform similarly to 4 month olds until the third day of training. The $25-\mathrm{rpm}$ procedure is sensitive to deficits found in both 12- and 18-month-old mice. Learning, nonetheless, is expressed by all age groups in both procedures. therefore, the effect of weight on response intensity must first be considered. Correlations between weight and Vmax were conducted within the three age groups to determine to what extent an animal's weight has contributed to the response intensity evoked by the startle stimuli. None of the correlations approached significance, indicating that weight had little effect on Vmax.

A 3 (age group) $\times 3$ (dB level) ANOVA indicated a significant main effect for age group $\left(\mathrm{F}_{[2,76]}=35.42\right.$; $P<0.001)$ and decibel level $\left(\mathrm{F}_{[1,76]}=196.58 ; P<0.001\right)$, and a significant interaction between age group and startle decibel level $\left(\mathrm{F}_{[2,79]}=27.41 ; P<0.001\right)$. Post hoc comparisons using the Tukey HSD test revealed differences in responding between groups at all $\mathrm{dB}$ levels. The only nonsignificant difference was between the 4-and 12-month-old startle responses to a $110-\mathrm{dB}$ stimulus (Fig. 7). Within subjects post hoc analyses using the Bonferroni test revealed that mice in the 4-month-old group showed a significant difference in Vmax between the decibel levels, showing larger responses to louder sounds. In all other age groups, however, response intensity did not necessarily increase as stimulus intensity increased. Although there were large startle responses shown by the 12-month-old group, no significant differences in Vmax were detected between the decibel levels. The 18-month-old group showed no difference in startle between 95 and $110 \mathrm{~dB}$, but a significant increase in Vmax was detected at $125 \mathrm{~dB}$. This indicates a deficit in responding to lower decibel levels in older mice.

The low Vmax values produced by 18-month old mice at 95 and $110 \mathrm{~dB}$ may indicate that the mice were not hearing the stimuli well. To examine the possibility that older mice did not hear the stimulus at 95 and $110 \mathrm{~dB}$, paired samples $t$ tests were used to examine differences in Vmax between no-stimulus trials (which record baseline chamber activity without presenting stimuli) and the lower decibel levels. Significant differences were observed between $95 \mathrm{~dB}$ and no-stimulus trials $\left(t_{[27]}=3.47, P<0.01\right)$ and between $110 \mathrm{~dB}$ and no-stimulus trials $\left(t_{[27]}=3.57\right.$, $P<0.01)$. In each case, the stimulus trials evoked a significantly higher Vmax than the no-stimulus trials, indicating that 18-month-old mice heard the stimuli and produced startle responses.

\section{Age Differences in Prepulse Inhibition}

Percentage prepulse inhibition (PPI) was calculated as follows: $[100-($ Prepulse + Startle/Startle Alone $) \times 100]$, where "Prepulse + Startle" is the average response in the prepulse trials, and "Startle Alone" is the average response in trials without prepulse stimuli (Tarantino et al. 2000). A 3 (age group) $\times$ 3 (prepulse decibel level) ANOVA indicated a significant age group effect $\left(\mathrm{F}_{[2,76]}=25.40 ; P<0.001\right)$ and a prepulse $\mathrm{dB}$ level effect $\left(\mathrm{F}_{[2,152]}=59.53 ; P<0.001\right)$, as well as an interaction between age group and prepulse $\mathrm{dB}$ level $\left(\mathrm{F}_{[4,152]}=15.92 ; P<0.01 ;\right.$ Fig. 8). Post hoc comparisons using

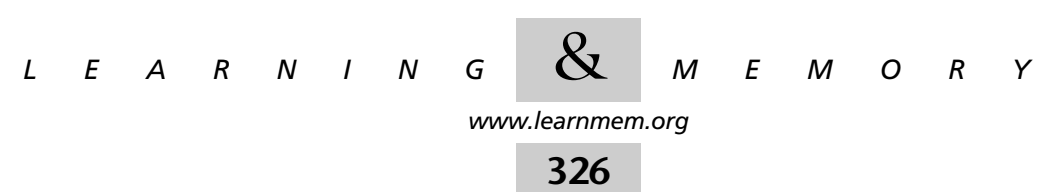


the Tukey HSD test examined differences in percent inhibition between age groups. These analyses revealed significant differences between both the 4- and 12-month-old groups and the 18-month-old group for the $80-\mathrm{dB}$ prepulse stimulus and the $85-\mathrm{dB}$ prepulse stimulus. The $90-\mathrm{dB}$ prepulse stimulus produced significant differences between the 12-month-old and the 18-month-old groups only. There were no differences between the 4 - and 12-month-old groups at any decibel level of the prepulse stimulus.

Examining the main effect of prepulse intensity within each age group, simple effects tests revealed the degree to which the prepulse decibel level is differentially effective at inhibiting the startle response in each age group. Significant differences were observed in the 12- $\left(\mathrm{F}_{[2,75]}=4.87\right.$; $P<0.05)$ and 18 -month-old $\left(\mathrm{F}_{[2,75]}=74.89 ; \quad P<0.001\right)$ groups. Post hoc tests using the Bonferroni adjustment for multiple comparisons revealed significant differences between all prepulse intensities except 85 and $90 \mathrm{~dB}$ in 12month-old mice, and between all prepulse intensities in 18month-old mice. Although 4-month-old mice showed inhibition of the startle response across all prepulse intensities, there were no significant differences. The change in PPI across prepulse intensities did approach significance, however, and a general trend was that louder prepulse decibel levels produced greater inhibition. This trend was observed across all age groups. The lack of any response inhibition at the $80-\mathrm{dB}$ level in the 18 -month-old mice likely indicates that the oldest mice were unable to hear the prepulse stimulus.

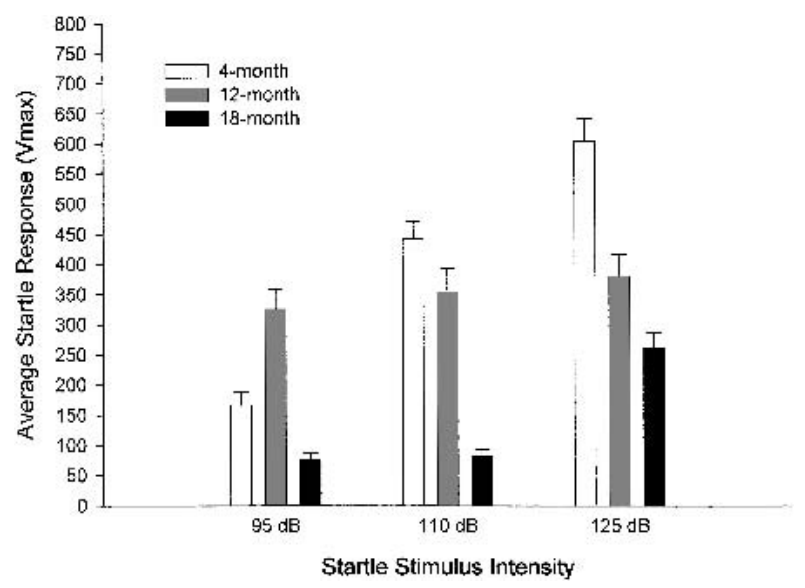

Figure 7 Maximum startle response to a 95-, 110-, or 125-dB stimulus in mice aged $4(n=24), 12(n=27)$, and $18 \quad(n=28)$ months. Young mice produce larger startle responses to louder stimuli. This is not necessarily true for older mice. Although 12month-old mice show strong reactions to the three $\mathrm{dB}$ levels, there is no difference between these reactions. Mice aged 18 months produce small startle responses to $95-$ and $110-\mathrm{dB}$ stimuli, but a significant increase in startle is not observed until the loudest stimulus is presented.

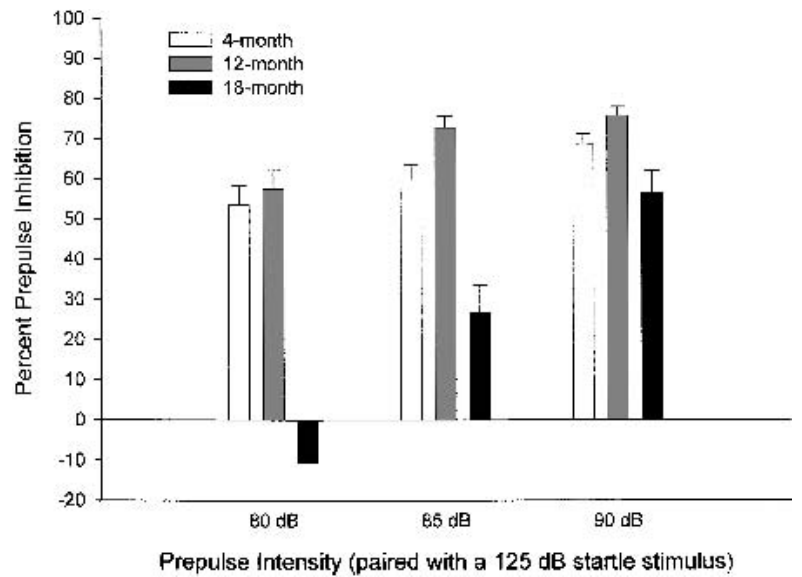

Figure 8 Percent inhibition of a startle response as a result of an 80-, 85-, or 90-dB prepulse stimulus being presented shortly before a 125-dB startle stimulus in mice aged $4(n=24), 12(n=27)$, and $18(n=28)$ months. A high percent PPI indicates that the prepulse inhibited the startle response. Mice aged 4 and 12 months perform at a similar rate, but 18-month-old mice are impaired. Because startle was not inhibited with an $80-\mathrm{dB}$ prepulse stimulus, the hearing threshold for 18-month-old mice is most likely between 80 and $85 \mathrm{~dB}$. Impairment in attention and sensory gating may be to blame for low inhibition at 85 and $90 \mathrm{~dB}$.

\section{Age Differences in Morris Water Task}

\section{Hidden PlatformTraining}

During acquisition, or hidden platform training, mice were repeatedly introduced to a pool filled with aversively cool water and were required to learn the location of a hidden escape platform using stationary contextual cues. The dependent measure of learning was latency to escape from the water by climbing onto the platform. Figure 9 depicts the mean latencies to escape for each day of hidden platform training. A 3 (age group) $\times 3$ (training session) repeatedmeasures ANOVA was conducted. A significant main effect of training session was discovered for latency to escape $\left(\mathrm{F}_{[2,142]}=64.97 ; P<0.001\right)$. There was no main effect for age and no interaction between age group and training session. This indicates that all age groups learned at equal rates, producing shorter latencies to escape over the 3 days of acquisition. Examining the main effect of training session within each age group, significant differences were observed in the $4-\left(\mathrm{F}_{[2,70]}=8.29 ; P<0.01\right), 12-\left(\mathrm{F}_{[2,70]}=24.62\right.$; $P<0.001)$, and 18-month-old groups $\left(\mathrm{F}_{[2,70]}=33.99\right.$; $P<0.001)$. Post hoc tests using the Bonferroni adjustment for multiple comparisons found that the 4-month-old group showed significant differences between sessions 1 and 3 , the 12-month-old group showed significant differences between all training sessions, and the 18-month-old group showed differences between session 1 and sessions 2 and 3 .

\section{Probe Trials}

After hidden platform training, the escape platform is removed from the pool. Probe trials are used to measure place

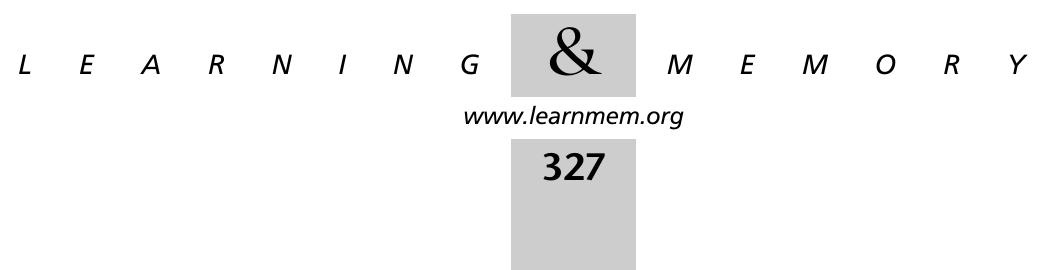


learning retention. One measure taken from probe trials is the number of times the mouse crosses over the former platform area. This measure is taken from each quadrant, and it is expected that mice will cross over the area in the trained quadrant more often than the same area in the other three untrained quadrants. All three age groups crossed the former platform area in the trained quadrant significantly more times than they crossed the same area in the other three quadrants (4-month: $\mathrm{F}_{[3,70]}=7.41, P<0.0001 ; 12$ month: $\mathrm{F}_{[3,70]}=10.41, P<0.0001 ; 18$-month: $\mathrm{F}_{[3,70]}=3.20$, $P<0.05$ ), with the exception that 18 -month-old mice did not differ between the trained quadrant and one adjacent untrained quadrant (Fig. 10A).

Another measure of retention is the time spent swimming in each quadrant, regardless of whether or not mice pass over the platform area. Figure 10B depicts the time spent swimming in each quadrant by the three age groups. Generally, the age group means indicated that mice preferred the former platform quadrant. A 3 (age group) $\times 4$ (quadrant) ANOVA revealed that all three age groups spent significantly more time swimming in the quadrant that formerly contained the escape platform than at least one other quadrant (4-month: $\mathrm{F}_{(3,70)}=8.89, P<0.0001 ; 12$-month: $\mathrm{F}_{(3,70)}=4.56, P<0.01 ; 18$-month: $\left.\mathrm{F}_{(3,70)}=4.07, P<0.05\right)$.

\section{Visible Platform Training}

In this condition, a flag was attached to the platform to mark its location below the surface of the water. A 3 (age group) $\times 2$ (training session) repeated-measures ANOVA comparing latency to escape between groups revealed a signifi-

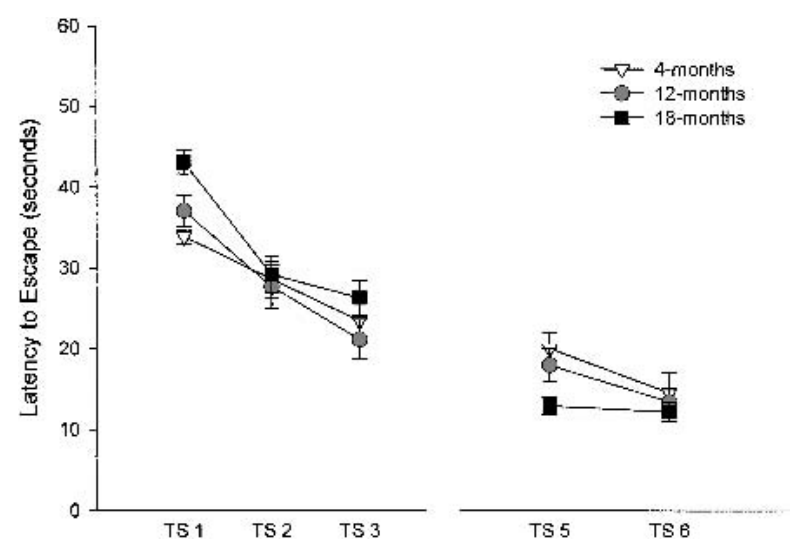

Figure 9 Latency to escape from the Morris water maze during sessions 1 through 3 (spatial learning) and sessions 5 and 6 (cued training) in mice aged $4(n=21), 12(n=26)$, and $18(n=28)$ months. TS indicates training session. Young mice outperform older mice on session 1 of spatial learning, and group differences disappear by session 2. A one-way ANOVA examining cued training indicated significant differences on session $5\left(\mathrm{~F}_{[2,74]}=4.48\right.$, $P<0.05)$, with the 18-month-old group outperforming the 4-month-old group. This is most likely a result based on the observation that young mice tend to show thigmotaxis, an inclination to circle the pool in search of an external escape rather than an internal one. cant training session effect $\left(\mathrm{F}_{[1,72]}=22.94, P<0.0001\right)$ and a significant interaction between age group and training session $\left(\mathrm{F}_{[2,72]}=3.91, P<0.05\right)$. The age group effect was not significant. A Bonferroni post hoc test determined that mice aged 4 and 12 months old performed significantly better from session 1 to session 2 of cued training, whereas 18-month-old swimming performance did not change between the two sessions.

\section{Sex Differences in Eyeblink Conditioning, Rotorod, Acoustic Startle, Prepulse Inhibition, and Morris Water Maze}

Early in the development of a mouse model of eyeblink classical conditioning in our laboratory, we heard from one experienced colleague that female mice conditioned more poorly than did male mice. To reduce costs, we aged only male mice, and our older age groups have few female mice. The only older female mice we tested at the age of 12 months were older breeders, and their data were handscored. A 2 (sex) $\times 5$ (training sessions) repeated-measures ANOVA indicated that there was not a significant sex difference or sex by training session interaction between the three males and four females tested with this method. The 4-month-old computer-scored group had eight males and eight females, but they were dispersed through the paired and explicitly unpaired conditions. A 2 (sex) $\times 10$ (training sessions) repeated-measures ANOVA on the three males and five females tested in the paired condition indicated that there was not a significant sex effect or sex by training session interaction in percentage of CRs in this age group. The same result occurred in the analysis of the five males and three females tested in the explicitly unpaired condition. Low power may have contributed to our inability to detect sex differences in eyeblink conditioning.

Sex differences in 15-rpm rotorod performance were analyzed for all groups. Using the dependent variable of latency to fall, a 3 (age group) $\times 2$ (sex) ANOVA was conducted on data from all three training sessions. The main effect for sex on training session 1 approached significance $\left(\mathrm{F}_{[1,77]}=3.76, P=0.056\right)$, with both the 4- and 12-monthold females outperforming the males. The main effect for sex on training sessions 2 and 3 was not significant, and the interaction between age group and sex was not significant on any training session. Sex differences in 25 -rpm rotorod performance were analyzed for all groups. Using the dependent variable of latency to fall, a 3 (age group) $\times 2$ (sex) ANOVA was conducted on data from all three training sessions. The main effect for sex and the interaction between age group and sex was not significant on any training session.

Sex differences in acoustic startle response were analyzed for all groups. A 3 (age group) $\times 2$ (sex) ANOVA was conducted on the dependent measure of Vmax for all startle decibel levels. The main effect of sex and the interaction 
A

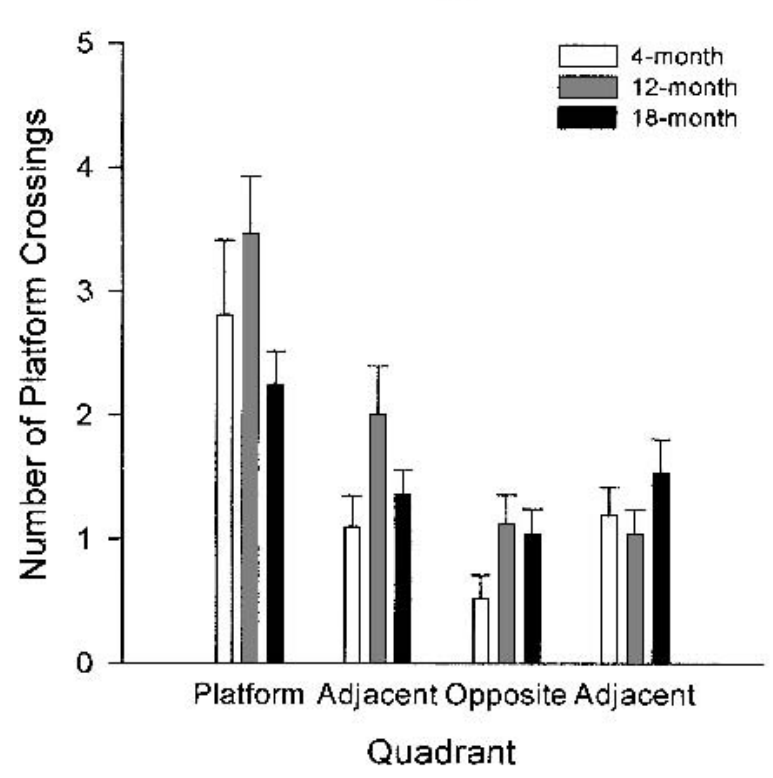

B

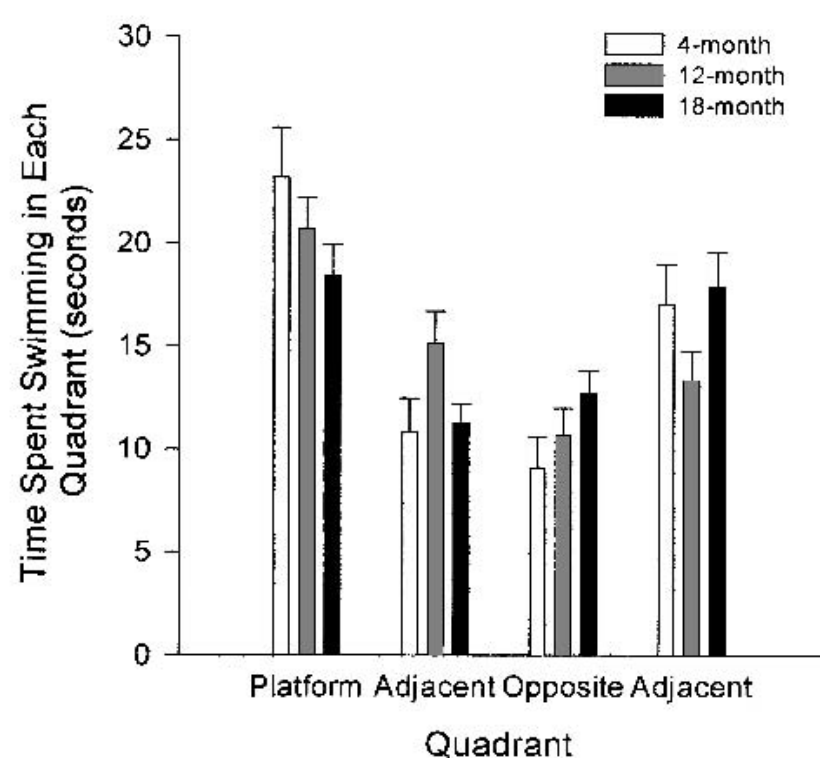

Figure 10 (A) Morris water maze platform crossings in trained and untrained quadrants during session 4 (probe trial) in mice aged 4 ( $n=21$ ), $12(n=26)$, and $18(n=28)$ months. In the Morris water maze probe trials, all mice crossed the area in the platform trained quadrant more times than they crossed the same area in untrained adjacent and opposite quadrants. $(B)$ Morris water maze time spent swimming in trained and untrained quadrants during session 4 (probe trial) in mice aged $4(n=21), 12(n=26)$, and $18(n=28)$ months. Mice generally spent more time swimming in the trained platform quadrant than they did swimming in the untrained adjacent and opposite quadrants.

between age group and sex was not significant at any startle decibel level. Sex differences in prepulse inhibition were analyzed for all groups. A 3 (age group) $\times 2$ (sex) ANOVA was conducted on percent prepulse inhibition for all startle decibel levels. The main effect of sex and the interaction between age group and sex was not significant at any decibel level.

Sex differences in Morris water maze performance were analyzed for all groups. Using the dependent measure of latency to escape, a 3 (age group) $\times 2$ (sex) ANOVA was conducted on training sessions 1 through 3 (hidden platform training) and sessions 5 and 6 (visible platform training). A significant main effect for sex was observed on training session $1\left(\mathrm{~F}_{[1,69]}=4.40, P<0.05\right)$, with 12-month-old females outperforming the males. The main effect for sex on training sessions 2 and 3 and sessions 5 and 6 were not significant, and the interaction between age group and sex was not significant on any training session. Sex differences in session 4 probe trial platform crossings in trained and untrained quadrants were analyzed using a 3 (age group) $\times$ 2 (sex) ANOVA. There were no significant main effects for sex and no significant interactions between age group and sex. Sex differences in time spent swimming in trained and untrained quadrants were analyzed using a 3 (age group) $x$ 2 (sex) ANOVA. There were no significant main effects for sex and no significant interactions between age group and sex.

\section{DISCUSSION}

In this study, several behavioral tests, including 250-msec delay eyeblink classical conditioning, were used to examine age differences between 4-, 9-, 12-, and 18-month-old C57BL/6 mice. The hypothesis that mice $>9$ months old (middle age) would be impaired in cerebellar-dependent tasks such as 250 -msec delay eyeblink classical conditioning and rotorod was supported. A second hypothesis, that mice $<24$ months would not be impaired in the hippocampally dependent Morris water maze, was also supported. These results parallel results from other species tested on delay eyeblink classical conditioning and also on hippocampally dependent behaviors and show that aging in behaviors dependent on the cerebellum occurs earlier than aging in behaviors dependent on the hippocampus. Results also indicate that the mouse is a useful model for investigating agerelated changes in learning and memory.

\section{Contributions from the Model System of Eyeblink Classical Conditioning}

Although the research reported here is purely behavioral, we are confident that the mouse model of eyeblink classical conditioning will have utility in elucidating neurobiological aging processes underlying behavioral aging changes. Richard Thompson's model of the neural circuitry involved in CS-US association and development of CRs in eyeblink conditioning identifies the cerebellum ipsilateral to the condi-

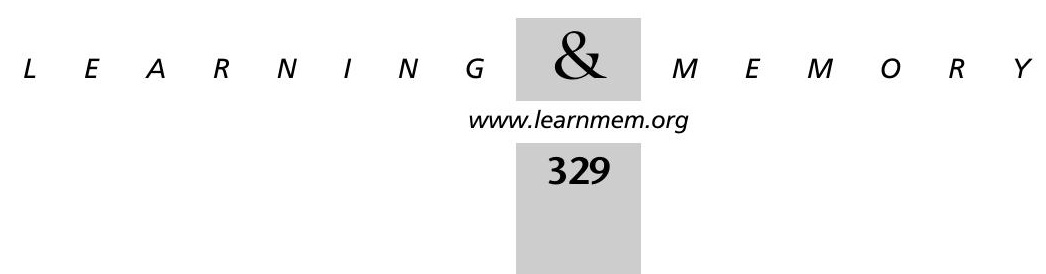


tioned eye as the essential structure (Thompson 1986; Kim and Thompson 1997). One working hypothesis regarding age-related impairment in eyeblink conditioning in mammals, including humans is that age-related changes in the cerebellum impair eyeblink conditioning beginning in middle age. Testing four age groups of mice with the 250msec delay eyeblink classical conditioning procedure, we have shown that mice $\geq 9$ months show impaired performance in cerebellar-dependent tasks when compared to 4-month-old mice.

In the eyeblink conditioning procedure, young 4-month-old mice rapidly developed CRs to the 85-dB 10$\mathrm{kHz}$ tone, whereas older mice aged 9, 12, and 18 months took longer to develop a comparable level of conditioning. It is possible that young mice developed CRs rapidly owing to their excessive sensitivity to a loud high-frequency stimulus. We used a $10-\mathrm{kHz}$ tone because this frequency is in the optimal hearing range of $\mathrm{C} 57 \mathrm{BL} / 6$ mice, including older mice (Henry and Chole 1980). Although hearing loss has been documented in aging mice of this strain, our results from the acoustic startle and prepulse inhibition tests indicate that C57BL/6 mice aged 12 and 18 months heard and responded to an $85-\mathrm{dB}$ auditory stimulus. Eighteen-monthold mice showed startle responses to a $95-\mathrm{dB}$ white noise stimulus, and both 85 - and 90-dB prepulse stimuli inhibited startle responses in these older mice. However, an 80-dB prepulse stimulus had no inhibiting effect on the startle responses of 18-month old mice. This result may indicate that the broadband hearing threshold of mice aged 18 months lies somewhere between 80 and $85 \mathrm{~dB}$. Both 4- and 12-month-old groups showed no signs of hearing impairment. Therefore, it is unlikely that differences in eyeblink conditioning performance are simply the result of impaired auditory acuity-although older mice probably hear the CS less clearly than do younger mice. This conclusion that hearing cannot account for the full magnitude of the age differences in conditioning is apparent in the case of 12month-old mice that showed no signs of hearing impairment but had impaired eyeblink conditioning. It is also the case that rotorod, a task that has no auditory requirement is impaired in 12- and 18-month-old mice.

The discrepancies between our results and the results of Kishimoto et al. (2001) may be associated with age differences in auditory acuity in C57BL/6 mice. We used a $10-\mathrm{kHz}$ tone to maximize the CS audibility for older mice. Kishimoto and associates used a $1-\mathrm{kHz}$ tone CS. Both groups tested $\mathrm{C} 57 \mathrm{Bl} / 6$ mice in the 250 -msec delay procedure using a CS intensity of 85-dB. Results of the two studies are at variance in regard to two aspects: (1) An impairment in conditioning was found in 9- and 12-month-old mice in the present study, whereas Kishimoto et al. found no impairment in 10-month-old mice; and (2) both studies detected reduced eyeblink classical conditioning in old mice, but the 18-month-old mice used in the present study showed a high plateau level of conditioning ( $\sim 80 \%$ CRs after the second day of training), whereas the 20-month-old mice tested in Kishimoto et al.'s study did not exceed a level of $\sim 30 \%$ CRs, even after 7 days of training. Perhaps 10-month-old mice in the Kishimoto et al. study heard the $1-\mathrm{kHz}$ tone CS well, whereas 20-month-old mice did not hear it as well. Data presented in Figure 1 of that study indicate that 4 - and 10 -month-old mice startled equally ( $>60 \%$ of the time) to the $1-\mathrm{kHz} \mathrm{CS}$, but 20-month-old mice startled less to that CS (40\%). We used a 10-kHz tone CS because studies of C57BL/ $6 \mathrm{~J}$ mice, including 23-month-old mice, show that their hearing thresholds are lowest for frequencies between 8 and 16 $\mathrm{kHz}$ (Zheng et al. 1999). By the age of 18 months, a $10-\mathrm{kHz}$ CS is clearly more audible than a $1-\mathrm{kHz}$ tone to $\mathrm{C} 57 \mathrm{Bl} / 6$ mice. Indeed, our 18-month-old mice were able to attain $80 \%$ CRs in training session 2 in our study. With a $1-\mathrm{kHz}$ tone CS, 20-month-old mice in the Kishimoto study produced only 30\% CRs after seven sessions.

The deficit in conditioning observed in both 12- and 18-month-old mice in the present study is not likely to reflect only changes in hearing acuity. An ANCOVA yielded a significant age effect on percentage of CRs for training session 1 when prepulse inhibition performance was held constant $(P=0.03)$. Note that the prepulse stimulus used in the present study was a white-noise stimulus and thus does not necessarily reflect the salience of the $10-\mathrm{kHz}$ tone used for eyeblink conditioning. We acknowledge that the influence of age-related changes in hearing acuity on eyeblink conditioning in aging mice requires further investigation.

Nonassociative factors, including hearing acuity, account for some of the age differences in our eyeblink conditioning data. However, there are some age-related associative learning effects present when the nonassociative effects are partialled out. Furthermore, in the case of rotorod performance, there are clear age effects independent of hearing acuity. An explanation for the observed age differences in these two cerebellar-essential tasks is age-related changes in the cerebellum, the structure essential for eyeblink classical conditioning and rotorod performance. With regard to eyeblink conditioning, this explanation has received support in other aging mammals such as rabbits (Woodruff-Pak et al. 1990a,b; Woodruff-Pak and Trojanowski 1996) and humans (Woodruff-Pak et al. 2001), with observations of a high correlation between the integrity of Purkinje cells and cerebellar volume and performance on eyeblink conditioning. Undertaking a comparative study of aging using the brains of 47 species, including mice, Dayan (1971) observed age-related decline in the number of Purkinje cells. Age-related changes in the cerebellum may account for the age-related deficits in conditioning and rotorod performance in mice. Motor systems, including the cerebellum, are essential in tasks such as the rotorod, a task that shows impairment in transgenic mice with abnormalities of motor neurons and cerebellar Pur-

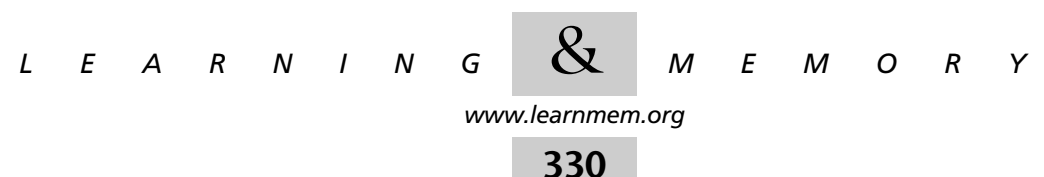


kinje cells (Lalonde et al. 1995). Transgenic mice that loose all cerebellar Purkinje cells within the first two months of life perform significantly worse in eyeblink conditioning than their do wild-type litter mates (Chen et al. 1996). Purkinje cell loss or cerebellar cortical aspirations do not prevent the acquisition of CRs. Rather loss of the cerebellar cortical machinery normally engaged in acquisition of CRs slows the rate of acquisition (Lavond and Steinmetz 1989; Chen et al. 1996).

\section{Challenges Posed by the Mouse Model of Eyeblink Classical Conditioning}

There is significant potential in the mouse model of aging and eyeblink conditioning to contribute to an understanding of neurobiological and behavioral mechanisms of learning, memory, and aging. However, the mouse model of eyeblink conditioning and aging is challenging to implement.

\section{Technical Problems: Activity Level, Size, and Electrode Continuity}

The high activity level of mice precludes restraint tactics that are effective in rabbits and makes it necessary to implant stimulating and recording electrodes into the obicularis oculi muscles so that mice can move freely during the conditioning procedure. The small size of mice makes such surgeries difficult. Once the surgery is complete and the mouse has recovered, implanted electrodes are not 100\% effective or headstages do not remain attached for the entire 10-day duration of the conditioning sessions. After 2 years of improving on our surgical skills and techniques, we have achieved a successful surgical-electrode efficacy of $75 \%$ and headstage maintenance rate of nearly $100 \%$. This means that we still lose some data on valuable mice we have aged for 8 to 18 months.

\section{Measurement Problems: Associative Learning Versus Learned Fear Responses}

Mice responded at a short latency (less than $80 \mathrm{~ms}$ ) to the $10-\mathrm{kHz}$ tone CS, making it difficult to score eyeblink conditioning records because the duration of what was scored as a startle response based on results from other species frequently extended to the period when a CR could be scored. There were age differences in the number and period in training of the onset of short-latency responses, with young mice being most likely to produce short-latency responses immediately in the first training session and older mice showing short-latency responses beginning in the second training session. We have spent hundreds of hours handand computer-scoring mouse eyeblink conditioning records to establish valid procedures and criteria, and we still do not believe that we have resolved all the issues. We have determined that white noise, with its multiple frequencies, may be a more optimal CS than a $10-\mathrm{kHz}$ tone because it evokes less startle in young $\mathrm{C} 57 \mathrm{BL} / 6$ mice and is still audible to the older mice.

The magnitude and duration of short-latency responses in young mice make it difficult to discriminate between associative learning and emotional responding especially in the short 250-msec period between CS and US. Theorists have proposed that conditioning with aversive stimuli results in at least two processes of learned behaviors: an initial emotional response and, later, an associative response (Mowrer 1947; Rescorla and Solomon 1967; Prokasy 1972). It has also been argued that processes of learned behavior develop in parallel rather than sequentially (Lavond et al. 1993). In either case, the critical brain substrates for the two processes are separate. Observations of the two processes in eyeblink classical conditioning studies indicate that conditioned emotional (fear) responses involve pathways mediating pain as well as limbic forebrain structures including the amygdala, whereas learned discrete responses involve the cerebellum and associated brainstem circuitry (Steinmetz and Thompson 1991). Our data in mice indicate that age differences may exist in both processes. Analyses of short-latency responses showed that they were significantly greater in young mice in the first training session and were hardly apparent in older mice at that point. In the second session, these responses increased significantly in 12- and 18-month-old mice. This pattern of an appearance of shortlatency responses after 100 training trials is not characteristic of $\alpha$ or startle responses that typically habituate within the first training session in rats, rabbits, and humans. Our analysis of these early responses indicated that they were maintained throughout training. In the case of 4- and 18month-old mice, the early latency responses were maintained for 10 sessions after they appeared in the first session in young mice and after the second session in older mice. We may be mistakenly calling these responses $\alpha$ or startle responses. They may be associative responses in mice that respond more rapidly than the other species that have been conditioned. The optimal CS-US interval for mice has yet to be determined empirically for mice, and there is no convention among laboratories for the latency window for startle responses or onset latency for a valid CR in mice. Data from the present study indicate that these parameters will be shorter for mice than they are for rats, rabbits, and humans.

Given the high rate of responding, including the high production of short-latency responses in young mice in the first training session, we nevertheless assert that there is significant associative learning in these animals that exceeds associative learning in mice in the 12- and 18month-old groups. First, although the 4-month-olds do show a high level of responding already on the first day, breaking up the first session into 10 blocks of 10 trials show a progressive increase in percentage of CRs. In the block-byblock analysis shown in Figure 3, there is a significant

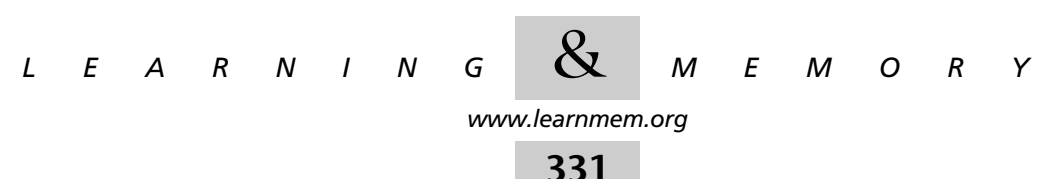


simple main effect of block in the first training session within the group of 4 -month-old mice $(P<0.0001)$, indicating that learning occurred throughout the first 100 trials of training.

Second, in contrast to the 4-month-old mice that appear to reach plateau level within the first 100 trials, both 12- and 18-month-old mice significantly improve eyeblink conditioning performance on the second day of training (Tukey post hoc tests, $P=0.034$ and 0.023 , respectively), indicating a somewhat slowed acquisition of CRs in older mice. This increase in CRs from the first to the second day is paralleled by a significant increase in short-latency $(\leq 80$ msec) responses in both 12 - and 18-month-old mice $(P=0.035$ and 0.008 , respectively), making a clear attribution of the increase to purely associative learning processes at the traditional CR onset latency difficult.

Third, the latency to remain on the rotorod at $25 \mathrm{rpm}$ of training correlates significantly with percentage of CRs on the first day of training. The cerebellum is critical for associative learning as assessed in delay eyeblink conditioning, and the cerebellum is also essential for rotorod performance. The emotional form of learning represented by the startle response uses nociceptive pathways and limbic forebrain structures (for review, see Yeomans and Frankland 1996). Thus, the observed correlation between performance on the two cerebellar tasks supports the validity of the interpretation that associative learning is assessed by our measures of the CR. With all the challenges posed by the aging mouse model of eyeblink conditioning, we continue to pursue this model because of its obvious value. In mice, it is possible to assess a number of behaviors that are much more challenging to assess in rabbits. Sensory gating and attention assessed with prepulse inhibition uses neural circuitry in the forebrain, including the nucleus accumbens and associated hippocampus, prefrontal cortex, and amygdala. One of the most widely used tests of rodent learning and memory, especially in research relevant to aging and $\mathrm{AD}$, is the Morris swim task, for which the hippocampus is essential in C57BL/6J mice (Logue et al. 1997b). For the investigation of age-related degenerative diseases such as $\mathrm{AD}$, the availability of transgenic mice that over- or underexpress acetylcholinesterase, of transgenic mice that lack specific nicotinic acetylcholine receptor subtypes, and the existence of techniques to switch on and off the transgenic effects are attractive features of mouse models. A hallmark of $\mathrm{AD}$ is the presence of neuritic plaques composed of the $\beta$-amyloid peptide $\left(A \beta_{1-42}\right)$ and neurofibrillary tangles composed of $\tau$ protein. A number of transgenic mouse models of these neuropathologies now exist. These transgenic mouse models of $\mathrm{AD}$ are the closest animal model of the disease that develops only in humans. These unique features of mouse models make the challenges of implementing eyeblink classical conditioning in aging mice appear potentially worthwhile.

\section{MATERIALS AND METHODS}

\section{Overview}

All mice, originally from Jackson Laboratory (Bar Harbor, Maine), were bred and raised in a colony room in the Association for Assessment and Accreditation of Laboratory Animal Care (AAALAC)accredited Central Animal Facility at Albert Einstein Medical Center. The colony room was temperature-and humidity-controlled and ventilated using a dedicated system. Room lighting was timed for a 12-h/12-h light/dark schedule. Mice were grouped by gender at weaning, with $\leq 12$ per cage, and housed individually beginning at least $48 \mathrm{~h}$ before testing. Housing consisted of a polycarbonate microisolator filtered-top cage. All mice had ad libitum access to sterile food (PMI autoclavable rodent lab diet RHI5010) and water. Research was given approval by Albert Einstein Medical Center's Institutional Animal Care and Use Committee (IACUC). Each mouse was weighed at the beginning of the study.

Previous experimenters have found that a fixed sequence of tasks is preferable to randomized test order, as randomization of task order will likely introduce extraneous variability (Logue et al. 1997a,b; Owens et al. 1997; Lalonde and Strazielle 1999). For this reason, tests were administered in the fixed order in which they are presented in Table 1. Testing took place Monday through Friday over a five-week period.

\section{Eyeblink Classical Conditioning}

Subjects consisted of $46 \mathrm{C} 57 \mathrm{BL} / 6$ mice aged to 4 ( $n=16$, eight males and eight females), $9(\mathrm{n}=7$, seven males and zero females), 12 ( $n=15,11$ males and four females), or $18(n=8$, eight males and zero females) months at the start of testing. These mice were tested in the 250-msec delay procedure and, in the case of half of the 4-month-old mice, in the explicitly unpaired condition. Additional mice for which data on rotorod, acoustic startle reflex, prepulse inhibition, and Morris water maze are reported were tested using long-delay or trace classical conditioning procedures that are not reported here. Animal husbandry and housing is as indicated in the Materials and Methods overview.

\section{Surgery}

Apparatus

For anesthesia, a nonrebreathing isoflurane administration system was constructed according to the specifications of Horne et al. (1998). The system consisted of a standard isoflurane vaporizer and an oxygen delivery system to deliver the isoflurane. An extension tube delivered anesthesia directly to the mouse. A scavenging tube attached to the evacuation side of the nonbreathing apparatus collected waste anesthetic gasses into an activated charcoal filter (f/ $\mathrm{air}^{\mathrm{t} / \mathrm{m}}$ ). A chamber was used to induce anesthesia, and two surgical platforms were used so that multiple surgeries could be performed simultaneously.

\section{General Procedures}

Surgery took place on training days 11 through 13 (Table 1). Mice were transported on a covered cart to the surgery room. Surgery was conducted under a standard ventilation hood. Anesthesia was induced with $\mathrm{O}_{2}+3 \%$ isoflurane at a flow rate of $1 \mathrm{~L} / \mathrm{min}$. The mouse was introduced to the induction chamber and was in a surgical plane of anesthesia within $1 \mathrm{~min}$. The isoflurane was then reduced to $2.5 \%$ as the mouse was placed on a surgical platform and fitted with a nose cone for anesthesia maintenance throughout the procedure. Ophthalmic ointment was applied to each eye to

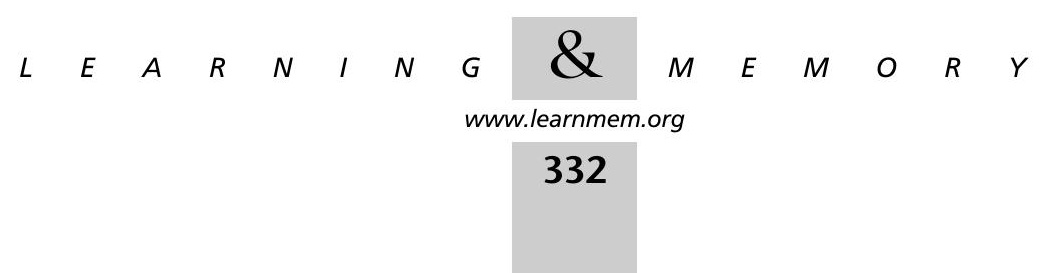


Table 1. Sequence of Behavioral Testing, Surgical, and Recovery Procedures for All Mice

\begin{tabular}{|c|c|c|c|c|c|c|c|c|c|}
\hline & \multicolumn{3}{|c|}{ Week 1} & \multirow{2}{*}{\multicolumn{3}{|c|}{$\begin{array}{c}\text { Week } 2 \\
\text { Morris water maze }\end{array}$}} & \multicolumn{2}{|c|}{ Week 3} & \multirow{3}{*}{$\begin{array}{c}\text { Weeks } 4 \text { and } 5 \\
\text { Eyeblink } \\
\text { classical } \\
\text { conditioning- } \\
250 \text { msec } \\
\text { delay procedure }\end{array}$} \\
\hline & \multirow[b]{2}{*}{ Rotorod } & \multirow{2}{*}{$\begin{array}{l}\text { Acoustic } \\
\text { startle } \\
\text { reflex/prepulse } \\
\text { inhibition }\end{array}$} & \multirow{2}{*}{$\begin{array}{c}\text { Morris } \\
\text { water } \\
\text { maze-hidden } \\
\text { platform } \\
\text { training }\end{array}$} & & & & \multirow{2}{*}{$\begin{array}{l}\text { Surgery for } \\
\text { eyeblink } \\
\text { conditioning- } \\
\text { electrode } \\
\text { implantation }\end{array}$} & \multirow[b]{2}{*}{$\begin{array}{c}\text { Recovery } \\
\text { from surgery }\end{array}$} & \\
\hline & & & & $\begin{array}{l}\text { Hidden } \\
\text { platform } \\
\text { training }\end{array}$ & $\begin{array}{l}\text { Probe } \\
\text { trial }\end{array}$ & $\begin{array}{l}\text { Cued } \\
\text { training }\end{array}$ & & & \\
\hline \multicolumn{10}{|l|}{ Day 1} \\
\hline \multicolumn{10}{|l|}{ Day 2} \\
\hline \multicolumn{10}{|l|}{ Day 3} \\
\hline \multicolumn{10}{|l|}{ Day 4} \\
\hline Day 5 & & & & & & & & 7 & $\nabla$ \\
\hline
\end{tabular}

prevent drying, and mice were covered with gauze strips to maintain normal thermoregulation.

\section{Surgical Procedures}

Four Teflon-coated stainless steel wires $(0.003$ in bare, 0.0045 in coated; A-M Systems, Inc.), soldered to a four-pin male header (Jameco Electronics), were implanted intramuscularly in the orbicularis oculi of the left upper eyelid. Wires were stripped of Teflon and carefully placed such that only the muscle-embedded wire was bare. To ensure that the wires did not move or recede back into the periorbital cavity, they were glued to the skull. The two wires most rostral were used to record differential electromyography (EMG) activity, and the two most caudal were used to deliver the eyeblinkeliciting stimulus. When all wires were placed, the four-pin header (headstage) was cemented to the skull and the incision was closed.

\section{Recovery}

After surgery, mice were given Baytril antibiotic $(85 \mathrm{mg} / \mathrm{kg}$ subcutaneously) to prevent infection, and Buprenex anesthetic (0.075 $\mathrm{mg} / \mathrm{kg}$ subcutaneously) for analgesia. Mice usually awoke within 15 min after completion of the procedure, and motor coordination appeared normal within a few hours. Recovery from surgery took place on test days 14 and 15 and the weekend following.

\section{Eyeblink Conditioning}

\section{Apparatus}

The conditioned eyeblink training apparatus consisted of four sound- and light- attenuating chambers (Med Associates, Inc.). Each chamber contained a clear polycarbonate mouse cage, a ventilation fan, and a wall-mounted speaker. A shielded four-conductor wire entered the ceiling of the chamber and was used to deliver a blinkeliciting stimulus to the orbicularis oculi and to record EMG activity. EMG activity was passed through a $300-$ to $5000-\mathrm{Hz}$ filter and amplified $\times 10 \mathrm{~K}$. The signal was then integrated and digitized before being read into an IBM-compatible system described by Chen and Steinmetz (1998) for processing. Data were collected in RAM and saved to a hard drive for offline analyses.

\section{General Procedures}

Eyeblink conditioning took place on test days 16 through 25 (Table 1). Each training session was controlled by a program written in
C++ language (Chen and Steinmetz, 1998) and run on an IMBcompatible 386 computer. The intertrial interval was random, ranging from 15 to $30 \mathrm{sec}$ at 1 -sec intervals. Mice were tested in groups of four. Each session lasted $\sim 1 \mathrm{~h}$.

\section{Testing Procedures}

Each mouse was placed in a clean cage within a chamber, and the four-conductor wire was fastened to its headstage. Mice were allowed to move freely around the cage during testing. The ventilation fan remained on and maintained a $70-\mathrm{dB}$ background noise. There were 100 trials presented in blocks of 10. Each block consisted of nine paired trials and one CS-only test trial. Paired trials presented a $350-\mathrm{msec}, 85-\mathrm{dB}, 10-\mathrm{kHz}$ tone $\mathrm{CS}$, followed $250 \mathrm{msec}$ after its onset by a $100-\mathrm{msec} 0.5-\mathrm{mA}$ shock US. It was determined by observation that a $0.5-\mathrm{mA}$ stimulus was sufficient to cause a blink/ head jerk in all mice. The CS and US co-terminated.

Each session was computer-scored using a Microsoft Excel macro, which analyzed each trial individually for responses. Whenever EMG activity in the orbicularis oculi, recorded in 3-msec bins, exceeded 5 SDs above baseline, a response was considered to have occurred. If a response took place in the first $100 \mathrm{msec}$ before the CS onset, the trial was excluded. For each session, several variables were observed. A startle or short-latency response was scored if the response occurred in the first $80 \mathrm{msec}$ after the CS onset. A CR was scored if a response occurred after the 80-msec startle period and before the 250 -msec US onset. On trials in which a short-latency response occurred, a CR could also be scored if it exceeded baseline by 5 SDs and occurred between 81 and $250 \mathrm{msec}$ after CS onset. A UR was scored if no response occurred before the US onset.

\section{Rotorod}

\section{Subjects}

Subjects consisted of $83 \mathrm{C} 57 \mathrm{BL} / 6$ mice aged to 4 ( $n=28,13$ males and 15 females), 12 ( $n=27,16$ males and 11 females), or 18 ( $n=28,27$ males and one female) months at the start of testing. Animal husbandry and housing is as indicated in the Materials and Methods overview.

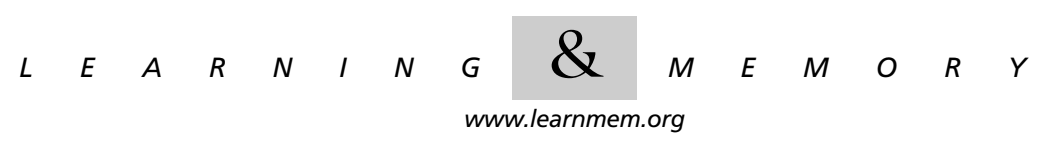




\section{Apparatus}

A four-lane motorized rotorod (San Diego Instruments) was used for testing locomotor coordination in mice. Each rod was $3 \mathrm{~cm}$ in diameter and $11 \mathrm{~cm}$ long, and maintained at $46 \mathrm{~cm}$ above the foam-covered base. An electronically controlled motor maintained the rod speed with the speed indicated on the front panel of the control chassis (with a resolution of $0.1 \mathrm{sec}$ ). Seven closely spaced photo beams detected the falling of the subject in each lane. The time to fall was shown on the timer display of each lane.

\section{General Procedures}

Rotorod testing took place on test days 1 through 3 (Table 1). Each training session consisted of eight trials. Mice were trained at speeds of 15 and $25 \mathrm{rpm}$ (counter-balanced for each age group), with four trials for each speed. There was a 5-min intertrial interval and a 30-min rest period between speed changes.

\section{Testing Procedures}

On each day, mice were placed on the rotating rod in the orientation opposite to the direction of rotation. Thus, to avoid a fall, subjects were required to locomote forward in a coordinated manner. Trials were discontinued if the subject did not fall within $\mathbf{8 0}$ sec. Latency before falling and time spent walking was calculated for each mouse at both rotation speeds.

\section{Acoustic Startle and Prepulse Inhibition}

\section{Subjects}

Subjects consisted of $79 \mathrm{C} 57 \mathrm{BL} / 6$ mice aged to 4 ( $n=24,10$ males and 14 females), 12 ( $n=27,16$ males and 11 females), or 18 ( $n=28,27$ males and one female) months at the start of testing. Animal husbandry and housing is as indicated in the Materials and Methods overview.

\section{Apparatus}

A two-channel SR-Lab System (San Diego Instruments) was used to test mice for reflexive startle responses to acoustic stimuli. The system included two $35 \times 33 \times 38.5-\mathrm{cm}$ sound-attenuating chambers that were ventilated and illuminated. The chambers contain a stabilimeter affixed to a clear Plexiglas cylinder $(16 \times 8.75 \mathrm{~cm})$ mounted to a Plexiglas frame $(12.5 \times 20.5 \times 0.6 \mathrm{~cm})$. The cylinder and frame are elevated $2.75 \mathrm{~cm}$ above a $30 \times 30 \times 4 \mathrm{~cm}$ Plexiglas base by four screws stationed under each corner of the stabilimeter frame. A 6-cm speaker, placed $27 \mathrm{~cm}$ above the cylinder, delivered acoustic stimuli. Startle responses were transduced by a perizoelectric accelerometer mounted beneath the stabilimeter frame. Output signals were digitized, rectified, and recorded as consecutive 1-msec readings on a Gateway Pentium II computer with San Diego Instruments Windows-compatible Startle Reflex software. Intensity of acoustic stimuli was verified by placing an audiometer (Radio Shack) in the Plexiglas cylinder, with the chamber door closed, and monitoring decibel levels through a viewing lens while running a test session.

\section{General Procedures}

Acoustic startle response and PPI testing took place on test day 4 (Table 1). The chamber light and ventilation fan remained on throughout the session. A $75-\mathrm{dB}$ white noise was presented through the overhead speaker to provide continuous diffuse background noise. Each session was controlled by San Diego Instruments software developed for the Microsoft Windows 98 platform. There were a total of 80 trials. The intertrial interval was random, ranging from 10 to $20 \mathrm{sec}$ at $1-\mathrm{sec}$ intervals, and all trials were presented in a pseudo-randomized order such that no two of the same trial-type were contiguous. Mice were tested in groups of two and each session lasted one-half hour.

\section{Testing Procedures}

Mice were placed in the cylinder for a 5-min acclimation period. Testing began immediately after acclimation. Startle trials consisted of a $40-\mathrm{msec}$ burst of white noise at one of three startle intensity levels $(95,110$, or $125 \mathrm{~dB})$. Acoustic startle consisted of a total of 15 trials with an inter-trial interval (ITI) of $15 \pm 5 \mathrm{sec}$. Each startle intensity level was presented five times. Prepulse inhibition testing immediately followed acoustic startle testing. Prepulse trials were $160 \mathrm{msec}$ in length and consisted of a 40-msec presentation of the 125 -dB startle stimulus $100 \mathrm{msec}$ after a $20-\mathrm{msec}$ precursor stimulus of white noise at one of three intensities $(80,85$, or $90 \mathrm{~dB})$. These prepulse intensities are 5,10, and $15 \mathrm{~dB}$ above the background noise and are each presented 10 times. In addition, 10 no-stimulus trials were presented to record baseline chamber activity, and 10 startle trials $(125 \mathrm{~dB})$ were also presented. There were a total of 50 trials presented during the prepulse inhibition testing session. Immediately after the session, 15 more startle trials were presented at the three startle intensities.

Four variables are recorded during the test session: Peak amplitude of the startle response (Vmax), average startle response over the 100-msec recording period, the amount of movement at the start of the trial (baseline activity), and the time required to reach peak startle response (latency). With the exception of nostimulus trials, recording of chamber activity only took place while the startle stimulus was being presented. Vmax was used as the primary measure of startle response.

\section{Morris Water Task}

\section{Subjects}

Subjects consisted of $75 \mathrm{C} 57 \mathrm{BL} / 6$ mice aged to $4(n=21,11$ males and 10 females), 12 ( $n=26,15$ males and 11 females), or 18 ( $n=28,27$ males and one female) months at the start of testing. Animal husbandry and housing is as indicated in the Materials and Methods overview.

\section{Apparatus}

The training apparatus was a circular pool, $100 \mathrm{~cm}$ diameter and 60 $\mathrm{cm}$ deep. The pool was located in a laboratory room containing camera and computer equipment, a screen, tables, and other furniture. The interior of the pool was painted white. The water temperature was maintained between $20^{\circ}$ and $26^{\circ} \mathrm{C}$, and the depth was $16 \mathrm{~cm}$. White nontoxic Crayola paint was used to make the water opaque. The hidden platform was a square white tile platform $\left(11 \mathrm{~cm}^{2}\right)$ with a surface that was $1 \mathrm{~cm}$ below the surface of the water. The visible platform was the same except a white flag $(10 \times 7 \mathrm{~cm})$ was suspended $15 \mathrm{~cm}$ above the platform by a wooden stick.

\section{General Procedures}

The Morris water task took place on test days 5 through 10 (Table 1). Around the test room were multiple cues such as furniture and graphic prints placed on the walls. Computer and camera equipment used to record the session were also visible to the mouse. Each trial was started by placing the animal in the water at the edge of the pool in a quadrant either opposite or adjacent to the quadrant containing the platform. The start locations were varied among

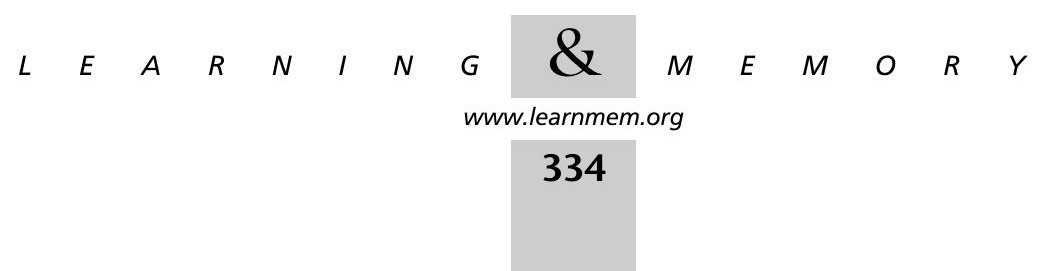


the three quadrants not containing the platform; with three different start locations being used in each block of four trials. The platform remained in the same location on every trial during the hidden platform task and varied across the four quadrants in the visible platform task. Each trial lasted $60 \mathrm{sec}$ or until the subject located the platform. Subjects that did not find the platform were guided to it and given a latency score of $60 \mathrm{sec}$. All subjects received a 15-sec rest period on the escape platform between trials. Between blocks of four trials, the mice were placed in individually heated plastic holding cages with paper towels in the bottom to absorb any moisture for at least $30 \mathrm{~min}$.

\section{Hidden Platform Training}

The mice were started from one of the three designated start locations, which were counterbalanced. Each subject was given three blocks of four trials each (12 trials per day per mouse) for three consecutive training sessions. Mice were given $60 \mathrm{sec}$ to locate the platform. Whether the platform was located or not, each mouse was required to spend $15 \mathrm{sec}$ on the platform between trials. Mice were returned to the holding cage between blocks. On the fourth training session, the subjects were given a probe trial, in which the platform was removed from the pool. After swimming for $60 \mathrm{sec}$, the mouse was removed from the pool and returned to its holding cage. The training trials and the probe trial were videotaped and recorded using the SMART (Spontaneous Motor $\underline{\text { Activity }} \underline{\text { Recording }}$ and Tracking) program manufactured by Panlab.

Several variables were measured during testing. The time to reach the platform (latency to escape) was recorded for each trial and averaged for each block of four trials. The probe trial was analyzed to measure the amount of time spent in each quadrant and the number of crossing made over the platform location in the trained quadrant and the equivalent area in the untrained quadrants.

\section{Visible Platform Training}

On the fifth and sixth training sessions, all mice were given the visible platform task in which the training was the same as the hidden platform version except the location of the platform and the start position were varied across trials. The latency to escape was recorded.

\section{ACKNOWLEDGMENTS}

Richard F. Thompson generously contributed to the development of the mouse model system in our laboratory. Richard Hinchliffe worked with us to develop surgical techniques for electrode implantation, and John Green assisted us with the development of techniques for data acquisition and scoring. We would like to thank Mikyung Ahn-Jeon for assistance with data collection and Dan Lyons and Isagani Santos of the Albert Einstein Healthcare Network Central Animal Facility for facilitating mouse surgery and for optimal health maintenance of our C57BL/6 colony. This research was supported by grants from the Albert Einstein Society and the National Institute of Aging, AG19411.

The publication costs of this article were defrayed in part by payment of page charges. This article must therefore be hereby marked "advertisement" in accordance with 18 USC section 1734 solely to indicate this fact.

\section{REFERENCES}

Berger, T.W., Berry, S.D., and Thompson, R.F. 1986. Role of the hippocampus in classical conditioning of aversive and appetitive behaviors. In The hippocampus (eds. R.L. Isaacson and K.H. Pribram), pp. 203-239. Plenum Press, New York, NY.

Chen, G. and Steinmetz, J.E. 1998. A general-purpose computer system for behavioral conditioning and neural recording experiments. Behav. Res. Methods Instrum. Comput. 30: 384-391.

Chen, L., Bao, S., Lockard, J.M., Kim, J.J., and Thompson, R.F. 1996. Impaired classical eyeblink conditioning in cerebellar lesioned and Purkinje cell degeneration ( $p c d$ ) mutant mice. J. Neurosci. 16: $2829-2838$.

Coffin, J.M. and Woodruff-Pak, D.S. 1993. Delay classical conditioning in young and older rabbits: Acquisition and retention at 12 and 18 months. Behav. Neurosci. 107: 63-71.

Daum, I. and Schugens, M.M. 1996. On the cerebellum and classical conditioning. Curr. Dir. Psychol. Sci. 5: 58-61.

Dawson, M.E., Schell, A.M., and Boehmelt, A., eds. 1999. Startle modification: Implications for neuroscience, cognitive science, and clinical science. Cambridge University Press, Cambridge, UK.

Dayan, A.D. 1971. Comparative neuropathology of ageing: Studies on the brains of 47 species of vertebrates. Brain 94: 31-42.

Disterhoft, J.F. and McEchron, M.D. 2000. Cellular alterations in hippocampus during acquisition and consolidation of hippocampus-dependent trace eyeblink conditioning. In Eyeblink classical conditioning: Animal models (eds. D.S. Woodruff-Pak and J.E. Steinmetz), Vol. 2, pp. 313-334. Kluwer Academic Publishers, Boston, MA.

Downey-Lamb, M.M. and Woodruff-Pak, D.S. 1999. Early detection of cognitive deficits using eyeblink classical conditioning. Alzheimer's Reports 2: 37-44.

Erway, L.C., Willott, J.F., Archer, J.R., and Harrison, D.E. 1993. Genetics of age-related hearing loss in mice, I: Inbred and F1 hybrid strains. Hearing Res. 65: 125-132.

Ferrante, L.S. and Woodruff-Pak, D.S. 1995. Longitudinal investigation of eyeblink classical conditioning in the old-old. J. Gerontol. B Psychol. Sci. Soc. Sci. 50: 42-50.

Green, J.T. and Woodruff-Pak, D.S. 2000. Eyeblink classical conditioning: Hippocampal formation is for neutral stimulus as cerebellum is for association-response. Psychol. Bull. 126:138-158.

Harrison, J. and Buchwald, J. 1983. Eyeblink conditioning deficits in the old cat. Neurobiol. Aging 4: 45-51.

Henry, K.R. 1983. Aging and audition. In: Auditory psychobiology of the mouse (ed. J.F. Willott), pp. 470-493. Charles C. Thomas, Springfield, IL.

Henry, K.R. and Chole, R.A. 1980. Genotypic differences in behavioral, physiological and anatomical expressions of age-related hearing loss on the laboratory mouse. Audiology 19: 369-383.

Horne, D., Ogden, B., Houts, J., and Hall, A. 1998. A nonbreathing anesthetic delivery system for mice. Lab. Animal 27(7): 32-34.

Hunter, K.P. and Willott, J.F. 1987. Aging and the auditory brainstem response in mice with severe or minimal presbycusis. Hearing Res. 30: $207-218$.

Ison, J.R., Agrawal, P., Pak, J., and Vaughn, W.J. 1998. Changes in temporal acuity with age and with hearing impairment in the mouse: A study of the acoustic startle reflex and its inhibition by brief decrements in noise level. J. Acoustic Soc. Am. 104: 1696-1704.

Jucker, M. and Ingram, D.K. 1997. Murine models of brain aging and age-related neurodegerative diseases. Behav. Brain Res. 85: 1-26.

Kim, J.J. and Thompson, R.F. 1997. Cerebellar circuits and synaptic mechanisms involved in classical eyeblink conditioning. Trends Neurosci. 20: 177-181.

Kishimoto, Y., Suzuki, M., Kawahara, S., and Kirino, Y. 2001. Age-dependent impairment of delay and trace eyeblink conditioning in mice. Neuroreport 12: 3349-3352.

Lalonde, R. and Strazielle, C. 1999. Motor performance of spontaneous murine mutations with cerebellar atrophy. In Handbook of molecular-genetic techniques for brain and behavior research: Techniques in the behavioral and neural sciences (eds. W.E. Crusio and R.T. Gerlai), Vol. 13., pp. 627-637. Elsevier Science, Amsterdam, The Netherlands.

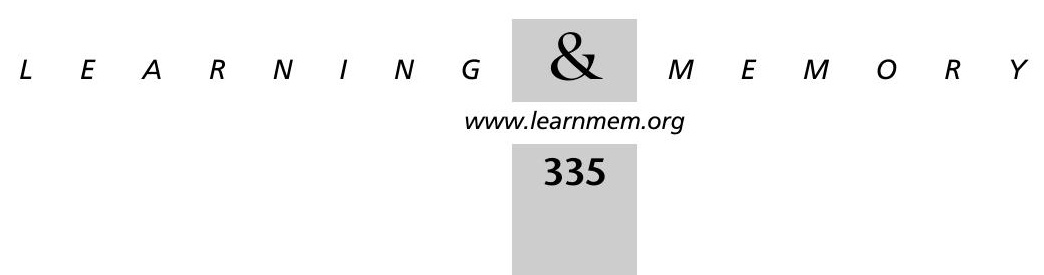


Lalonde, R., Bensoula, A.N., and Filali, M. 1995. Rotorod sensorimotor learning in cerebellar mutant mice. Neurosci. Res. 22: 423-426.

Lavond, D.G. and Steinmetz, J.E. 1989. Acquisition of classical conditioning without cerebellar cortex. Behav. Brain Res. 33: 113-164.

Lavond, D.G., Kim, J.J., and Thompson, R.F. 1993. Mammalian brain substrates of aversive classical conditioning. Annu. Rev. Psychol. 44: 317-342.

Logue, S.F., Owen, E.H., Rasmussen D.L., and Wehner, J.M. 1997a Assessment of locomotor activity, acoustic and tactile startle, and prepulse inhibition of startle in inbred mouse strains and $F_{1}$ hybrids: Implications of genetic background for single gene and quantitative trait loci analyses. Neuroscience 80:1075-1086

Logue, S.F., Paylor, R., and Wehner, J.M. 1997b. Hippocampal lesions cause learning deficits in inbred mice in the Morris water maze and conditioned-fear task. Behav. Neurosci. 111: 104-113.

Mikaelian, D.O. 1979. Development and degeneration of hearing in the C57/b16 mouse: Relation electrophysiologic responses from the round window and cochlear nucleus to cochlear anatomy and behavioral responses. Laryngoscopy 34: 1-15.

Mowrer, O.H. 1947. On the dual nature of learning: A reinterpretation of "conditioning" and "problem-solving." Harvard Educ. Rev. 17: $102-148$

Owen, E.H., Logue, S.F., Rasmussen, D.L., and Wehner, J.M. 1997. Assessment of learning by the Morris water task and fear conditioning in inbred mouse strains and $F_{1}$ hybrids: Implications of genetic background for single gene and quantitative trait loci analyses. Neuroscience 80: 1087-1099.

Parham, K. and Willott, J.F. 1988. Acoustic startle response in young and aging C57BL/6J and CBA/J mice. Behav. Neurosci. 102: 881-886.

Prokasy, W.F. 1972. Developments with the two-phase model applied to human eyelid conditioning. In Classical conditioning: Current research and theory (eds. A.H. Black and W.F. Prokasy), Vol. 2, pp. 147-199. Appleton-Century-Crofts, New York, NY.

Rescorla, R.A. and Solomon, R.L. 1967. Two-process learning theory: Relationships between Pavlovian conditioning and instrumental learning. Psychol. Rev. 74: 151-182.

Solomon, P.R., Stowe, G.T., and Pendlebeury, W.W. 1989. Disrupted eyelid conditioning in a patient with damage to cerebellar afferents. Behav. Neurosci. 103: 898-902.

Solomon, P.R., Levine, E., Bein, T., and Pendlebury, W.W. 1991. Disruption of classical conditioning in patients with Alzheimer's disease. Neurobiol. Aging 12: 283-287.

Stanton, M.E. and Freeman Jr., J.H. 2000. Developmental studies of eyeblink conditioning in the rat. In Eyeblink classical conditioning Animal models (eds. D.S. Woodruff-Pak and J.E. Steinmetz), Vol. 2, pp. 135-134. Kluwer Academic Publishers, Boston, MA.

Steinmetz, J.E. and Thompson, R.F. 1991. Brain substrates of aversive classical conditioning. In Neurobiology of learning, emotion and affect (ed. J. Madden), pp 97-120. Raven Press, New York, NY.

Tarantino, L.M., Gould, T.J., Druhan, J.P., and Bucan, M. 2000. Behavior and mutagenesis screens: The importance of baseline analysis of inbred strains. Mamm. Genome 11: 555-564.

Thompson, R.F. 1986. The neurobiology of learning. Science 233: 941-947.

Thompson, R.F. 2000. Discovering the brain substrates of eyeblink classical conditioning. In Eyeblink classical conditioning: Animal models. (eds. D.S. Woodruff-Pak and J.E. Steinmetz), Vol. 2, pp.17-49. Kluwer Academic Publishers, Boston.

Weiss, C. and Thompson, R.F. 1991. The effects of age on eyeblink conditioning in the freely moving Fischer-344 rat. Neurobiol. Aging 12: 249-254.

Woodruff-Pak, D.S. and Thompson, R.F. 1988. Classical conditioning of the eyeblink response in the delay paradigm in adults aged 18 to 83 years. Psychol. Aging 3: 219-229.

Woodruff-Pak, D.S. and Trojanowski, J.Q. 1996. The older rabbit as an animal model: Implications for Alzheimer's disease. Neurobiol. Aging 17: 283-290.

Woodruff-Pak, D.S. and Steinmetz, J.E., eds. 2000a. Eyeblink classical conditioning: Applications in humans, Vol. 1. Kluwer Academic Publishers, Boston, MA.

- 2000b. Eyeblink classical conditioning: Animal models, Vol. 2. Kluwer Academic Publishers, Boston, MA.

Woodruff-Pak, D.S., Lavond, D.G., Logan, C.G., and Thompson, R.F. 1987. Classical conditioning in 3-, 30- and 45- month old rabbits: Behavioral learning and hippocampal unit activity. Neurobiol. Aging 8: 101-108.

Woodruff-Pak, D.S., Cronholm, J.F., and Sheffield, J.B. 1990a. Purkinje cell number related to rate of classical conditioning. Neuroreport 1: $165-168$.

Woodruff-Pak, D.S., Finkbiner, R.G., and Sasse, D.K. 1990b. Eyeblink conditioning discriminates Alzheimer's patients from non-demented aged. Neuroreport 1: 45-49.

Woodruff-Pak, D.S., Papka, M., Romano, S., and Li, Y.-T. 1996. Eyeblink classical conditioning in Alzheimer's disease and cerebrovascular dementia. Neurobiol. Aging 17: 505-512.

Woodruff-Pak, D.S., Vogel III, R.W., Ewers, M., Coffey, J., Boyko, O.B., and Lemieux, S.K. 2001. MRI-assessed volume of cerebellum correlates with associative learning. Neurobiol. Learn. Mem. 76: 342-357.

Yeomans, J.S. and Frankland, P.W. 1996. The acoustic startle reflex: Neurons and connections. Brain Res. Rev. 21: 301-314.

Zheng, Q.Y., Johnson, K.R., and Erway, L.C., 1999. Assessment of hearing in 80 inbred strains of mice by ABR threshold analyses. Hearing Res. 130: $94-107$.

Received June 6, 2002; accepted in revised form August 8, 2002. 


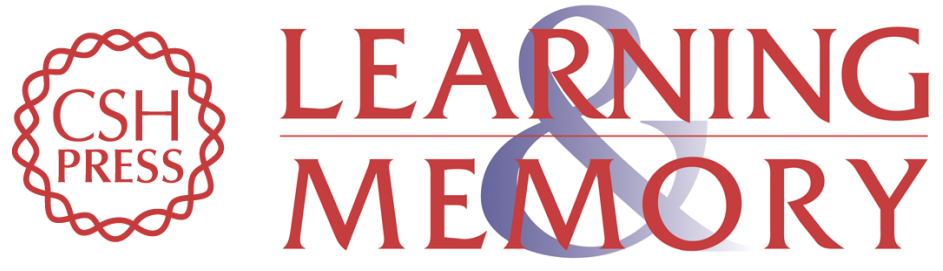

\section{Age-Related Impairment in the 250-Millisecond Delay Eyeblink Classical Conditioning Procedure in C57BL/6 Mice}

Richard W. Vogel, Michael Ewers, Charlene Ross, et al.

Learn. Mem. 2002, 9:

Access the most recent version at doi:10.1101/lm.50902

References This article cites 36 articles, 2 of which can be accessed free at:

http://learnmem.cshlp.org/content/9/5/321.full.html\#ref-list-1

License

Email Alerting Receive free email alerts when new articles cite this article - sign up in the box at the Service top right corner of the article or click here. 